Ks. Stanisław LONGOSZ

(Lublin, KUL)

\title{
JAN PAWE⿺ II A ORGANIZACJA POLSKICH STUDIÓW NAD ANTYKIEM CHRZEŚCIJAŃSKIM
}

Aby lepiej zrozumieć organizacyjne zasługi ks. kardynała Karola Wojtyły, późniejszego papieża Jana Pawła II wobec antyku chrześcijańskiego, trzeba się cofnąc do połowy lat 60 -tych. Wprawdzie w polskich seminariach duchownych uczono wówczas patrologii, ale traktowano ją często jako naukę pomocniczą historii Kościoła lub dogmatyki, a nawet filologii klasycznej, w całej zaś Polsce było zaledwie 5 specjalistów z tej dziedziny - ks. dr Wacław Eborowicz w Pelplinie, ks. dr Wojciech Kania w Tarnowie, o. dr Andrzej Bober SJ w Krakowie, ks. dr Szczepan Pieszczoch w Gnieźnie i ks. prof. dr hab. Marian Michalski na jedynej obsadzonej akademickiej katedrze patrologii Akademii Teologii Katolickiej w Warszawie; na nieobsadzoną zaś katedrę patrologii KUL sprowadzono z Paryża o. dra Jana Marię Szymusiaka SJ, któremu jednak do końca nie zatwierdzono habilitacji. Na KUL-u literaturą chrześcijańską zajmowała się na sekcji Filologii Klasycznej Wydziału Nauk Humanistycznych p. doc. dr Leokadia Małunowiczówna, zaś archeologię i sztukę wczesnochrześcijańską wykładała na sekcji Historii Sztuki, dojeżdżająca z Warszawy p. dr Barbara Filarska, a na Wydziale Teologicznym dojeżdżający z Pelplina ks. dr Antoni Liedtke; w Metropolitalnym Seminarium Duchownym w Krakowie czynił to ks. dr Bolesław Przybyszewski. Nie było żadnej formalnej akademickiej instytucji zajmującej się antykiem chrześcijańskim w szerszym tego słowa znaczeniu. Przewodniczącym Komisji Episkopatu d/s Nauki Katolickiej był w tym czasie od r. 1968 ks. kard. Karol Wojtyła ${ }^{1}$; to właśnie z jego inspiracji i pod jego patronatem powstały w tym czasie: w 1969 r. - Międzywydziałowy Zakład Badań nad Antykiem Chrześcijańskim KUL w Lublinie, w 1977 r. Sekcja Patrystyczna przy Komisji Nauki Episkopatu Polski, a w latach 19781980 zaczął się tworzyć w Tarnowie Instytut Patrystyczny w ramach Papieskiego Wydziału Teologicznego w Krakowie. Warto tu przypomnieć zasługi ks. kardynała Karola Wojtyły w organizowaniu się i działalności tych trzech instytucji.

1 Por. A. Boniecki, Kalendarium życia Karola Wojtyły, wyd. 2 poprawione i uzupełnione, Kraków 2000, 316. 


\section{MIĘDZYWYDZIAEOWY ZAKEAD BADAŃ NAD ANTYKIEM CHRZEŚCIJAŃSKIM KUL}

Założycielami tejże międzywydziałowej akademickiej instytucji naukowej były dwie osoby: p. doc. dr Leokadia Małunowiczówna - kierownik Łacińskiej Katedry Filologii KUL i o. doc. dr Jan Maria Szymusiak SJ - zajmujący Katedrę Patrologii w Instytucie Historii Kościoła na Wydziale Teologicznym KUL. Oni to postanowili stworzyć instytucję, która by w sposób zorganizowany i systematyczny zajęła się studiami szeroko pojętego antyku chrześcijańskiego I-VIII wieku. Gdy długo nie znajdowali zrozumienia i poparcia zarówno w środowisku uniwersyteckim, jak i episkopalnym (m.in. u ks. Prymasa kardynała S. Wyszyńskiego) udali się jesienią 1968 r. ze swym pomysłem do przewodniczącego Komisji Episkopatu d/s Nauki Katolickiej - ks. kardynała Karola Wojtyły w Krakowie. Podczas spotkania, którego treść przypomni za półtora roku Ksiądz Kardynał przy otwieraniu sympozjum goszcząc u siebie badaczy antyku chrześcijańskiego (13-14 II 1970), przedstawili swoje racje i potrzebę powołania tego rodzaju instytucji. Ksiądz Kardynał wysłuchał ich i zrozumiał, stwierdzając równocześnie potrzebę ustalenia wkładu myśli patrystycznej w odnowę zdrowej teologii, zapoczątkowaną przez Sobór Watykański II. Uznał potrzebę stworzenia na KUL-u specjalnej instytucji naukowej, służącej badaniom nad szeroko pojętą starożytnością chrześcijańską, oraz zorganizowania w najbliższym czasie sesji naukowej, skupiającej ludzi zajmujących się tą tematyką - zarówno literaturą i teologią patrystyczną, jak i sztuką i archeologią wczesnochrześcijańską. Doc. L. Małunowiczówna zasugerowała wówczas, by na tego rodzaju spotkanie zaprosić jednego z najwybitniejszych ówczesnych włoskich patrologów - ks. kard. Michaele Pellegrino z Turynu. Ks. kardynał K. Wojtyła poparł tę myśl obiecując do takiego zaproszenia dołączyć swój polecający list, swoje pośrednictwo i pomoc w zorganizowaniu tego przedsięwzięcia, gdyż przewidywał trudności w jego realizacji. Po uzyskaniu tego rodzaju aprobaty i zrozumienia od przewodniczącego Komisji Episkopatu d/s Nauki Katolickiej, organizatorzy - o. doc. J.M. Szymusiak i doc. L. Małunowiczówna z otuchą i zapałem zabrali się do realizacji swych planów. Pani Docent niedługo przed śmiercią w 1980 r. tak oto wspominała owo spotkanie: „Przed jedenastu laty powstała we mnie myśl, że należy stworzyć w Polsce ośrodek badań nad antykiem chrześcijańskim. Chciałam znać stanowisko „wuja Karola”. Uzyskałam dłuższą audiencję w Krakowie. Przedstawiłam samą koncepcję i możliwości jej realizacji. Uznał celowość inicjatywy, która miała ułatwić Kościołowi w Polsce powrót do Ojców, do źródeł chrześcijaństwa. Nie tylko udzielił swego błogosławieństwa, ale obiecał także pomagać. Pamiętam: dzień był dżdżysty, pochmurny, a ja drogę powrotną odbyłam z ogromną radością w sercu; mając takie poparcie byłam pewna, że wszystko 
dobrze się ułoży"2. W ten oto sposób, m.in. dzięki moralnemu poparciu ks. kardynała K. Wojtyły powstał w 1969 r. Międzywydziałowy Zakład Badań nad Antykiem Chrześcijańskim na Katolickim Uniwersytecie Lubelskim: najpierw 18 kwietnia Senacka Komisja d/s Nauki, a następnie 13 maja Senat Akademicki uchwaliły jego erygowanie oraz zatwierdziły jego regulamin, czyli o rok wcześniej niż powstanie Instytutu Patrystycznego „Augustinianum” w Rzymie (maj 1970). Na kierownika Zakładu został powołany o. doc. dr Jan Maria Szymusiak SJ, a na jego zastępcę - doc. dr Leokadia Małunowiczówna.

Ksiądz kardynał K. Wojtyła nie tylko przyczynił się swoim poparciem do powstania Międzywydziałowego Zakładu Badań nad Antykiem Chrześcijańskim, ale też później wielokrotnie wspierał go finansowo: „nieraz wysyłałam do Krakowa SOS i zawsze nadchodził ratunek" - pisała później p. doc. L. Małunowiczówna (por. fot. 1$)^{3}$. Owszem, w swoim arcybiskupim pałacu w Krakowie przy ul. Franciszkańskiej aż trzykrotnie gościł i raz w swoim krakowskim Metropolitalnym Seminarium Duchownym, wspierał finansowo lub opłacał jego ogólnopolskie sympozja, zapewniając im nie tylko bazę materialną, ale, zanim Zakład osiągnął już swoje znaczenie, angażując się nawet swoim autorytetem w zapraszanie prelegentów. W miarę możliwości osobiście je otwierał i podsumowywał, na ich rozpoczęcie lub w trakcie odprawiał Msze św. z homilią w swojej domowej kaplicy dla uczestników, podpisywał listę obecności i na ile mu czas pozwalał, był na nich obecny. Okazało się to zwłaszcza podczas pierwszego goszczonego u siebie dwudniowego sympozjum (13-14 II 1970), na które swoim listem zapraszał prelegentów, a wśród nich m.in. kard. M. Pellegrino z Turynu, ks. prof. M. Michalskiego z ATK czy prorektora ChAT-u - ks. prof. J. Klingera. Wspominany ks. kard. M. Pellegrino w odpowiedzi na prośbę organizatorów i ks. kard. Wojtyły najpierw obiecał przyjazd i wygłoszenie prelekcji pt. Wkład myśli patrystycznej do Vaticanum II, wyrażał, jak wskazuje jego list, wdzięczność i podziw dla organizatorów, a nawet pytał, w jakim języku ma to uczynić, a gdyby okoliczności mu przeszkodziły i z jakiegoś powodu nie mógł osobiście przyjechać - przesłać tekst swego wystąpienia (por. niżej kopię listu ks. kard. M. Pellegrino), ale później, gdy zmieniono termin sympozjum z września na luty, odmówił przyjazdu i przesłania tekstu referatu usprawiedliwiając się brakiem czasu, o czym powiadomił ks. kard. K. Wojtyłę w Krakowie telegramem końcem stycznia 1970 roku ${ }^{4}$. Również ks. prof. M. Michalski, który miał mówić nt. Znaczenie źródet wczesnochrześcijańskich dla poznania istoty chrześcijaństwa i realizowania aggiornamento, odmówił udziału w sympozjum

${ }^{2}$ L. Małunowicz, ,Wuj” Karol, w: Być czlowiekiem i chrześcijaninem (W nurcie zagadnień posoborowych 12), red. B. Bejze, Warszawa 1980, 18.

3 Tamże, s. 19.

${ }^{4}$ Por. telegram przesłany do ks. kard. K. Wojtyły na ul. Franciszkańską 3 w Krakowie: „Byłem w Turynie, kardynał Pellegrino nie przyjedzie, referatu gotowego nie ma i nie przyśle = pozdrawiam Cader +". 
tłumacząc się brakiem zdrowia ${ }^{5}$. W sympozjum, podczas którego wygłoszono ostatecznie 6 prelekcji ${ }^{6}$, uczestniczyło 47 osób z całej Polski, zainteresowanych antykiem chrześcijańskim. Otworzył je i zagaił ks. kard. K. Wojtyła, który, na ile pamiętam i informuje zachowany protokół ${ }^{7}$, najpierw powitał uczestników jako gospodarz domu, jako ordynariusz krakowski i jako przewodniczący Komisji Episkopatu d/s Nauki Katolickiej w imieniu całego krakowskiego środowiska naukowego, 13 seminariów duchownych znajdujących się w Krakowie i Polskiego Towarzystwa Teologicznego z siedzibą w Krakowie, życząc wszystkim, by w tym mieście dobrze się czuli i owocnie obradowali, oddając im do dyspozycji swój dom i kaplicę, oraz zapraszając na wszystkie posiłki. Następnie przypomniał prehistorię rozpoczynającej się aktualnie sesji zaznaczając, że przed półtora roku podczas długiego spotkania w arcybiskupim pałacu w Krakowie z o. doc. J.M. Szymusiakiem SJ i doc. L. Małunowiczówną uznał potrzebę powołania na KUL-u naukowej instytucji zajmującej się studiami nad antykiem chrześcijańskim oraz organizowania spotkań badaczy zajmujących się tą dziedziną ${ }^{8}$. Potem przez dłuższy czas, mimo wielu zajęć wizytacyjnych, uczestniczył w obradach podpisując jako pierwszy listę obecności ${ }^{9}$.

Następnego dnia 14 lutego o godz. 8.00 rano Ksiądz Kardynał przewodniczył Mszy św. koncelebrowanej w swojej domowej kaplicy, podczas której wygłosił do uczestników homilię komentując najpierw słowa Izajasza proroka (58, 9-14) z I czytania: „Twoi ludzie zabudują prastare zwaliska, wzniesiesz budowle odwiecznych fundamentów. I będą cię nazywać naprawcą wyłomów, odnowicielem rumowisk - na zamieszkanie", a następnie ewangeliczną perykopę o Piotrze chodzącym po morzu (Mt 14, 22-23). Kaznodzieja wskazał dalej na rolę badaczy źródeł chrześcijańskich, jako rolę budowniczych. Patrologia bowiem nie tylko informuje o tym, co było oraz jest świadectwem wiary starożytnych pokoleń, ale ma również wytyczać drogę na przyszłość. „Będą cię nazywać naprawcą wyłomów i odnowicielem rumowisk". Zadaniem badaczy antyku chrześcijańskiego jest więc naprawianie i ukazywanie ścieżek wiodą-

${ }^{5}$ Por. 2 listy Profesora do Księdza Kardynała (Warszawa, 20 XI 1969 i 25 I 1970), w: Akta Zaktadu. Sympozja I: sympozjum 2.

${ }^{6}$ Oto program sympozjum (13-14 II 1970): ks. doc. dr Jan M. Szymusiak (KUL), Koncepcja pracy badawczej nad Ojcami Kościoła; doc. dr Leokadia Małunowiczówna (KUL), Antyk chrześcijański; ks. prof. Jerzy Klinger (ChAT), Tradycja starochrześcijańska w doktrynie i duchowości Kościołów Wschodnich; ks dr Wacław Hryniewicz (KUL), Patrystyka i ekumenizm; ks dr Andrzej Bober SJ (Kraków - OO. Jezuici), Wkład nauki polskiej do badań nad antykiem chrześcijańskim; ks. dr Szczepan Pieszczoch (Gniezno - Metropolitalne Seminarium Duchowne), Zagraniczne ośrodki badań nad antykiem chrześcijańskim. Teksty niektórych tych referatów zob. RTK 26 (1979) z. 4.

${ }^{7}$ Por. Akta Zakładu. Sympozja I: sympozjum 2.

${ }^{8}$ Por. Boniecki, Kalendarium życia Karola Wojtyły, s. 310-311: „13-14 II 1970 Kraków, Pałac Arcybiskupi, sesja naukowa poświęcona problematyce badań nad antykiem chrześcijańskim. Ks. Kardynał: zagajenie"; J.M. Szymusiak, Zjazd patrystyczny w Krakowie, AnCra 2 (1970) 451-452.

${ }^{9}$ Por. niżej - kopia listy obecności. 
cych do źródeł chrześcijaństwa, oraz wytyczanie nowych dróg prowadzących ku przyszłości. Nie należy się przy tym lękać i zniechęcać, ale iść naprzód jak Piotr kroczący odważnie po wzburzonych falach, który zaufał Chrystusowi. Większość powyższych uwag potwierdzają załączone niżej kopie dokumentów.

\section{Cepia}

L'ARCIVESCOVO DO TORINO

Torino, 18 Marzo 1969

Bminenza Reverendisaima e carissima,

in risposta all'amabile Sus lettera del $16 \mathrm{c.m.}$, desidero anzitutto esprimere all'Eminenza Vostra e agli esimil cultori di scienze petristiche della Sua Nazione la mia ammirazione per l'impegno con cul ki si promuovono gli studi sull antichitè cristiona.

Ajohe per confermare tali gentimenti, serò ben lieto di intervenire al fam Congresso previsto per I'uItima decate di settembre, salvo * che circoatanze impreviste non consentisgero il viaggio in Polonia.

Sarò Grato a Vostra Eminenza se vorrà informare in proposito gli organizzatori, dai qua:.1 atterco w.teriori ineormazioni. I medesimi mi vorranno anche significare, in quale lingua dovrà essere pronuncia to il discorso/giacché purtroppo non conosco il polacco/, scegliendo frs 1'11taliano, il francese, l'inglese, il tedesco, lo spagnolo o il latino.

Voglia gradire, Eminenza Reverendisgima, i sensi del mio fratermo ossequio in osculo pecis.

devmo e affmo

$$
/ \text { / + Michele Gard.Pellegrino, arcivescovo }
$$

A Sua Eminenza Reverendisaina

11 Signor Cardinale Carlo Wojtyle

Plazza Remuria 2 a

00153 R O M A

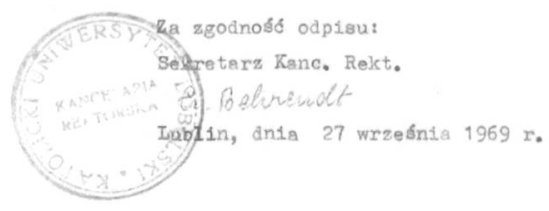




\section{Odpis}

3 maja 69

+ Czcigodny Kgięse Profesorze,

W czasie ostatniej mojej bytności w Rymie zwrócixem się do Kard. 4. Pellegrino w sprawie naszej sesji. Odpowiedź Kardynaxa zacaczam w odpisie Pynike a niej, że możemy liczyć przynajmiej na nadesłanie referatu. Thciazbym bardzo w zwį̨zku z tym porozmawias z Księdzem Prafesorem

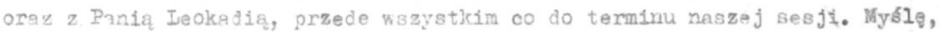
he bęczie ją nożna odbvó najwczeániej : listopadzie, gdyź w ciøgu wrześnis 1 do poxowy peździernika będę musiał najprawdopodobniej znajdowac się poza Polskeq.

Eącre serdeczne pozdrowielin in Xr.eto

/ $/$ + Karol Kard. Wojtyza

Przewielebny Ksiądz Profesor

Ks. doc. Ir J.Szymusisk

W a s z \& w a

00. Jezuic1

Za zgođnoś odpisu:

Sekretarz Kanc. Rekt.

Q. Po elueside

Iyudin. 27 wrzeŕnia 1969. 
KAROL KARDYNAE WOJTYEA ARM JSKUP METROPOLITA KRAKOWSKI
Kraków, dnia 3 maja 1969 r.

\section{Droga Pani Leokadjo,}

w załączeniu przesyłam odpisy pism

jakie skierowałem do ks.doc.dr.J.Szymusiaka w sprawie naszej sesji $i$ serdecznie pozdrawiam w Chrystusie Panu i Jego Matce
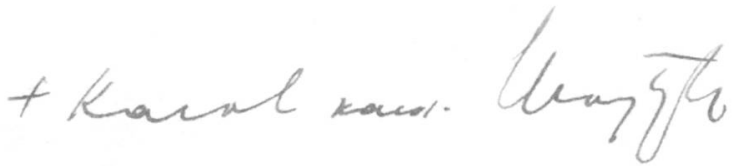

$\int_{\text {Kp. } 1733: 67-5000-\mathrm{R}-54(177)}$

Międzywydziałowy Zakład Badań

nad Antykiem Chrześcijariskim KUL

Lublin, 13.1. 970 .

$\alpha \cdot d_{2}, 3,4,5,6 / 70 / \mathrm{ACh}$

WPan

Otrupreali: Prof. M. Gogace

Prof. ............

ks. Prof. A. fankouph

la Prop M. Vurolíarah

ki. Praf 7. gariarl.

W najbliźszych dniach J.E.Ks.Kardynał Karol Wojtyła

zwróci się do Pana Profesora z zaproszmiem do udziału w Sesji Naukowej w Krakowie.

Sesja ta organizowana jest przez Międzywydziałowy Zakład Badań nad Antykiem Chrzescijańskim KUL, który po zatwierdzeniu przez Senat kuLu w maju ub.roku, rozpoczął swoją działalność z biezącym rokiem akademickim.

Pragnąłbym wyjaśnić, że bardzo nam zaleźy na ewentualnej współpracy z Panem Profesorem w dziedzinie badań nad antykiem chrześcijańskim, który obejmuje także specjalnoś́ Pana profesera. Pozwalam więc sobie zwrócić się o zyczliwe ustosunkowanie się do tego zaproszenia. 

Litta obecwosici na obraolach predpotrudmiongch$$
\text { 2. Las. Ste/aw svardest }
$$

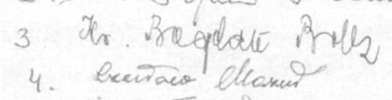$$
\text { 5. Hamua Filarshea }
$$$$
\text { 6. HDofouts }
$$$$
\text { 7. Olunteun Boguidu oD }
$$

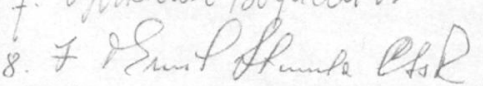$$
\text { s bu Wimenty ungoor }
$$$$
\text { 10. Duceh Po IL }
$$$$
\text { 41. Jun Jirzeninuthi }
$$$$
12 \text {. }
$$$$
13 \text {. }
$$

14. Ko. Hieorysiat Snichimietrmi

15. O. Karjuniers Zuelooushin

16. M. Rumaun Rudréécush

17. An. Ayumunit Thejinar

18. bs Helesander forida cisint.

$1 \quad x$. Stanidaw Longon

25. X. Fr. Drecakoushi

21. H. Stanoina Semoh SAB

22. x trlatpriar trojey

23. hes, Meurngle Mhlíftowivz

24. He Dising Putmsingh

25. Ma Tadenn Laurstors:

26. La. Limpan

27. Li. Larian Banesenk

28. is Elvard efomich

29. Damute Sunsh

30. Bemard Trurizyt

3. Xifrjeich Nania

32
34 fliareh

35. Ko /i. Brows.

36. V. Hriprewick

37. $\times$. Awhey Jantonstei

38. Anoms Bobersy-

ss. Miveriy

40

41. Lliat unowiorerm.

42 L.Pf Klinger

43. Zapeniwe Ca a pouth

44. Va Jenoen Fomunk

45. S. Saleyi Padenc in

46. X Jan m. Srymusiak is

kt. $x$ w. Eborowics 
Na tymże sympozjum ks. Kardynał jako przewodniczący Komisji Episkopatu d/s Nauki Katolickiej zasugerował, by w najbliższym czasie przeprowadzić weryfikację nauczycieli uczących dyscyplin patrystycznych w polskich seminariach duchownych. Sam obiecał, że własnym podpisem poprze i roześle do wszystkich seminariów duchownych ankietę, by na jej podstawie można było ustalić faktyczny stan i wyciągnąć wnioski, co do polepszenia sytuacji w dydaktyce patrologii, języka łacińskiego i greckiego oraz archeologii wczesnochrześcijańskiej $^{10}$. Opracowanie wyników tejże ankiety i zaprezentowanie ich na jednym z kolejnych ogólnopolskich spotkań powierzono ks. mgr. Romanowi Andrzejewskiemu. Podsumowania całego sympozjum dokonał kierownik Zakładu o. J.M. Szymusiak SJ, zamknął je zaś, jak stwierdza protokół z tejże sesji, Ksiądz Kardynał: „Sesja została zamknięta przez J.Em. Kard. K. Wojtyłę. W ostatnich swych słowach Ksiądz Kardynał podkreślił, że dla niego, jako przewodniczącego Komisji Episkopatu d/s Nauki Katolickiej, bardzo cenne były wiadomości o stanie badań w Polsce w dziedzinie patrologii"11.

Drugim sympozjum, którego uczestników gościł w swoim arcybiskupim pałacu Ksiądz Kardynał K. Wojtyła, była dwudniowa sesja zorganizowana 26-27 maja 1971 r.; było to piąte już z kolei ogólnopolskie spotkanie poświęcone tłumaczeniom tekstów. Wzięło w nim udział 37 osób, a wygłoszono 7 referatów ${ }^{12}$; wśród prelegentów występowały, m.in. takie sławy filologiczne, jak prof. Jerzy Łanowski z Wrocławia, prof. Jerzy Schnayder z Warszawy i prof. Jerzy Starnawski z Łodzi. Od tego sympozjum zaczęto się wzajemnie informować, co kto tłumaczy lub co ma już przetłumaczone z pism Ojców Kościoła, o czym przypominano już w zaproszeniach.

Również to sympozjum miał według programu otworzyć Ksiądz Kardynał, chociaż nie wiemy dziś z całą pewnością, czy tego faktycznie dokonał, bo jego nazwisko nie figuruje na liście obecności, ani nie ma o tym wzmianki w urzędowym protokole sympozjum, jakkolwiek potwierdza to prasa ${ }^{13}$. Nie wiemy

${ }^{10}$ Por. ankietę niżej, w II rozdziale: Sekcja Patrystyczna.

11 Por. Akta Zakładu. Sympozja I: sympozjum 2; zob. też Szymusiak, Zjazd patrystyczny w Krakowie, s. 452: „Sesja została zamknięta przez J.Em. Kardynała, który w ostatnich słowach podkreślił, że dla niego, jako przewodniczącego Komisji Episkopatu do Spraw Nauki Katolickiej, bardzo cenne były wiadomości o stanie badań patrystycznych w Polsce i życzył dalszej owocnej pracy".

12 Por. program sympozjum (26-27 V 1971): Dr Zofia Klimajówna (KUL), Archaizmy, neologizmy $i$ dialektyzmy w utworze literackim; prof. dr Jerzy Schnayder (emerytowany prof. UBB), Wybrane z literatury antycznej zwroty grzecznościowe $i$ inne formuly konwencjonalne; prof. dr Jerzy Łanowski (UBB), $Z$ warsztatu thumacza antycznego dramatu (Eurypides, Menander); Konwersatorium pod przewodnictwem dr Janiny Ławińskiej-Tyszkowskiej (UBB) - Petroniusz i Apulejusz; dr Julia Mrukówna (Kraków - PAN), Kłopoty ttumacza „Historii” Długosza; prof. dr Jerzy Starnawski (U€), Przekład jako zjawisko kultury; dr T. Micewicz (UW), Językoznawcze aspekty teorii przekładu.

${ }^{13}$ Por. Sympozjum patrologów i badaczy antyku chrześcijańskiego. Informacja własna, „Słowo Powszechne” z 9 VI 1971 roku: „Sympozjum otworzył ks. kard. Karol Wojtyła, który 
również, w jakim zakresie w nim uczestniczył, bo zwłaszcza w pierwszym dniu (26 V) był wyjątkowo zajęty, gdyż wtedy miało miejsce pierwsze posiedzenie Komisji Przygotowawczej Synodu, na którym On prezentował swój referat pt. „Problem 900. rocznicy św. Stanisława oraz synodu prowincjalnego”. Wiadomo natomiast, że drugiego dnia (7 V) najpierw przewodniczył rano w swojej domowej kaplicy koncelebrze duchownych uczestników i wygłosił do wszystkich okolicznościową homilię ${ }^{14}$, a później uczestniczył we wspólnym obiedzie, podczas którego kierownik Zakładu podziękował mu za gościnę, On zaś, jak informuje protokół sesji, wyraził zadowolenie, że mógł pomóc Zakładowi oraz polecał swe usługi na przyszłość, by można było dalej prowadzić owocne badania nad Ojcami Kościoła: „Podczas obiadu, w którym uczestniczył Jego Eminencja Ksiądz Kardynał Karol Wojtyła, Kierownik Zakładu dokonał podsumowania obrad oraz złożył serdeczne podziękowanie Gospodarzowi za gościnę. Ksiądz Kardynał w kilku słowach wyraził zadowolenie, iż mógł dopomóc naszemu Zakładowi oferując swe apartamenty na obrady oraz zaznaczył, że gotów jest nimi zawsze w razie potrzeby służyć, byśmy mogli owocnie kontynuować badania nad Ojcami Kościoła"15.

Odpowiedzialnym za stronę organizacyjną w Krakowie uczynił Ksiądz Kardynał niedawno mianowanego wicerektora Metropolitalnego Seminarium Duchownego - ks. Jana Ligęzę. On to, jak wskazują zachowane listy organizatorów do Księdza Kardynała, miał się postarać o noclegi, miejsce obrad i posiłków dla uczestników, a także rozesłać zaproszenia w imieniu goszczącego Gospodarza. To z nim kontaktowało się później bezpośrednio kierownictwo Zakładu przy załatwianiu organizacyjnej strony sympozjum ${ }^{16}$.

Trzecie dwudniowe sympozjum, którego uczestników gościł Ksiądz Kardynał w Krakowie, odbyło się 12-13 maja 1974 r. obok kilku referatów problemowych (koncepcja patrologii oraz jej miejsce wśród dyscyplin teologicznych) i okolicznościowych (1600. rocznica śmierci św. Efrema Syryjczyka i św. Ata-

zwracając uwagę na wciąż wzrastające zainteresowanie w Kościele piśmiennictwem starochrześcijańskich pisarzy, podkreślił, że ten powrót do źródeł prowadzi do coraz głębszego zrozumienia istoty Kościoła i jego misji w naszych czasach".

14 Por. Boniecki, Kalendarium życia Karola Wojtyły, s. 348: „26-27 V 1971 Rezydencja arcybiskupów krakowskich - sympozjum patrologiczne. $27 \mathrm{~V}$ godz. 8: kaplica domowa, Msza św. koncelebrowana z kazaniem dla profesorów patrystyki”.

15 J.M. Szymusiak, Protokót z sympozjum, w: Akta Zakładu. Sympozja I: sympozjum 7.

16 Por. List J.M. Szymusiaka do ks. Jana Ligęzy z 11 maja 1971 roku: „Przesyłamy także odpis listu wysłanego do jego Eminencji ks. Kardynała z dnia 28 kwietnia, w którym postawiliśmy kilka pytań dotyczących strony organizacyjnej"; zob. też Zaproszenie organizatorów: „Serdecznie zapraszamy do wzięcia udziału w V Sympozjum thumaczeniowym, które odbędzie się w Krakowie, w rezydencji Księdza Kardynała Wojtyły w dn. 26 i 27 maja. Obrady będą odbywały się według załączonego programu [...]. Informacje o miejscu noclegu uczestników Sesji zostaną przesłane bezpośrednio z Krakowa przez ks. J. Ligęzę, któremu J. Eminencja powierzył stronę organizacyjną". 
KATOLICKI UHIWERSYTET LUBELSKI

Międzywydziałowy Zakład Badań

nad Antykiem Chrześcijańskim

Lublin, AL. Ractawickie 14

\author{
Lublin, dnia 7 kw1etnia $19^{71} \mathrm{r}$.
}

\author{
Jego Earinenoja \\ Ksiqda Kardynał Karol Wojtyła \\ Przewodniczący dla Spraw Nauki \\ przy \\ Ep1 skopac1e Polski
}

Jeszeze raz bardzo serdeeznie dziękująe za umozliwienie od-

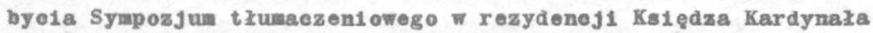
przesyłany wykaz zgłoszonych ośbb. Podajemy rómniez prow1zoryczna obsade referent6w. Ponil nie posiadamy jeszoze dakładnyoh danyoh odnónie do $1 \mathrm{ch}$ noclegu, dane te prześleny w terninte poźniejszym.

Jednocześnte zapytuy $y$, do kogo many s1e zwróc16 w sprawach organizaoyjnyoh Sympozjum, by nie zablerá́ bardzo cennego ezasu Kø1ędza Kardynała.

Lączyay wyrazy gkębokiej cze1

K1 erownik Zakładu

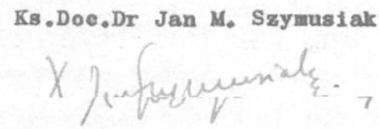




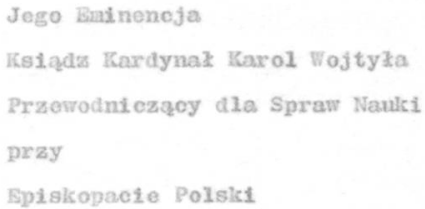

Pontewaś dotychezas nie otrzymaliśmy odpowiedzi na list datowany v dn. 7 kwietnia br, termin zaś sympozjum zbliza się, ośmielamy się postawí kilka pytań dotyeząoych strony organizacyjnej tego spotkania, nianowicie:

1/ komu Jego Emineneja zleciz stronę organizacyjna sympozjum,

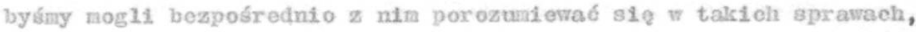
jak :

a/ punict informeyjny

b/ noelegi

of miejsce 1 godziny posizków

a/ miejsce obrad.

2/ czy Jego Enineneja ưaża za nozliwe wysłanie zaproszoń z Krakowa w inieniu Jego Enineneji, jak to miało niejsee w rolcu ubległym /w takim wypadku natyohmlast nadeśleny adresy osób zgłoszonyeh/. Z ubiegłorocznego doáwiadezenla wiery, ze uczestnloy czull 31ę bardzo zaszezyeent osobistya zaproszentem przez Księdza Kardynaza.

$3 /$ ezy 1 kiedy byzby potrzebry przyjazd asystenta naszego zakladu celem ostatecznogo zakatwionia spraw organizaeyjnych. Prosilibyśny o zaskawe odpewiodź w nozliwie szybkim torminie, gdył dane te są nan nízozędne przy ukzadaniu szezegózowego program zaje6 podezas sesj1, programy natomiast cholelibyśny rozesłać do uczestmik6w wajbliższym czosie. Lagozyny wyrazy gięboktej ezei i serdecznego podzi elcowania Z-oa Kierownike Zalkzadu listadia detunowiern. Doc.dr Leokadía Mazunowi ezóma 
nazego Aleksandryjskiego), miało ono przede wszystkim charakter sprawozdawczy $^{17}$. Wówczas to wobec Przewodniczącego Komisji Episkopatu d/s Nauki Katolickiej ks. dr Roman Andrzejewski przedstawił sytuację dydaktyczną patrologii w polskich Seminariach Duchownych ${ }^{18}$ na podstawie przeprowadzonej wcześniej ankiety; ks. mgr Władysław Wójcik - sytuację nauczania języków klasycznych; p. doc. Barbara Filarska i p. dr Tytus Górski - sytuację nauczania archeologii chrześcijańskiej w Polsce; ks. dr Emil Stanula - sytuację patrologii na polskich Wydziałach Teologicznych ATK, KUL, w Krakowie i Poznaniu. Złożono też sprawozdania z działalności: Sekcji Patrologii ATK, Międzywydziałowego Zakładu Badań nad Antykiem Chrześcijańskim KUL, oraz ruchu wydawniczego zajmującego się publikacjami patrystycznymi. W sympozjum wzięło udział 46 osób świeckich i duchownych.

Program tej konferencji, dotyczącej głównie wykładowców języków klasycznych i dyscyplin patrystycznych w Wyższych Seminariach Duchownych omówiła wcześniej doc. L. Małunowiczówna z księdzem Kardynałem K. Wojtyłą na audiencji 26 X 1973 r. w Krakowie. On to wówczas zdecydował, by „łącznikiem" organizacyjnym między nim a Zakładem Badań nad Antykiem Chrześcijańskim w Lublinie był lektor języków klasycznych z miejscowego Metropolitalnego Seminarium Duchownego - p. dr Tytus Górski, który już 1 grudnia miał w tej sprawie udać się do Lublina, gdzie miano wspólnie ustalić treść ankiety, skierowanej do nauczycieli języków klasycznych, patrologii i archeologii chrześcijańskiej oraz do polskich wydawnictw katolickich, planujących wydawanie publikacji patrystycznych. I tym razem nie wiemy, w jakim zakresie Ksiądz Kardynał uczestniczył w obradach sympozjum, bo nie zachowała się lista obecności. Był on niewątpliwie wówczas bardzo zajęty, bo w tym samym czasie w miejscowym Seminarium Duchownym odbywała się rejonowa konferencja

${ }^{17}$ Por. program sympozjum (Kraków, 12-13 II 1974): Sytuacja dydaktyki antyku chrześcijańskiego w seminariach duchownych: a) ks. mgr Władysław Wójcik (Kielce - Seminarium Duchowne), Języki klasyczne; b) ks. dr Roman Andrzejewski (KUL), Patrologia; doc. dr Barbara Filarska (KUL) i dr Tytus Górski (Kraków - Metropolitalne Seminarium Duchowne), Archeologia chrześcijańska; ks. dr Emil Stanula (ATK), Problemy dydaktyczne w zakresie patrologii na wydziałach teologicznych (poza seminariami); Sprawozdanie z działalności: a) Sekcji Patrologii ATK, b) Katedry Patrologii KUL, c) placówek naukowych w Krakowie i Poznaniu, d) Zakładu Badań nad Antykiem Chrześcijańskim, e) ruchu wydawniczego dotyczącego antyku chrześcijańskiego; ks. dr Szczepan Pieszczoch (Gniezno - Metropolitalne Seminarium Duchowne), Koncepcja patrologii $w$ dydaktyce seminaryjnej; ks. dr Andrzej Santorski (Warszawa - Metropolitalne Seminarium Duchowne), Miejsce patrologii w dyscyplinach teologicznych; ks. dr Andrzej Bober SJ (Kraków): Stan obecny i potrzeby polskiej patrystyki; prof. dr Leokadia Małunowiczówna (KUL), Możliwości pracy nad antykiem chrześcijańskim i jego propagowanie w Polsce; ks. doc. dr hab. Wojciech Kania (Tarnów - Seminarium Duchowne), Referat okolicznościowy dla uczczenia 1600 rocznicy śmierci Efrema Syryjskiego; ks. mgr Stanisław Longosz (Rzym), Referat okolicznościowy dla uczczenia 1600 rocznicy śmierci Atanazego.

${ }^{18}$ Por. R. Andrzejewski, Sytuacja dydaktyczna patrologii w Seminariach Duchownych, RTK 26 (1979) z. 4, 53-61. 
dekanatów Krakowa. Wiadomo jednak, że drugiego dnia - 13 maja rano przewodniczył w swojej domowej kaplicy koncelebrze duchownych uczestników oraz wygłosił do wszystkich homilię ${ }^{19}$. Według programu Ksiądz Kardynał jako przewodniczący Komisji d/s Nauki Katolickiej miał podsumować wyniki całego sympozjum i omówić otwierające się perspektywy dla wiedzy o antyku chrześcijańskim. Warto tu na koniec przytoczyć zdanie protokołu z drugiego dnia obrad, że już wówczas, ks. dr Roman Andrzejewski „postulował utworzenie Sekcji Patrystycznej, która zajęłaby się opracowaniem programu studiów w Seminariach Duchownych oraz wydaniem odpowiedniego podręcznika" ${ }^{20}$.

Trzeba tu też wymienić trzydniowe międzynarodowe sympozjum Zakładu Antyku, zorganizowane 31 V - 2 VI 1976 r. w Krakowie, wprawdzie nie w rezydencji Księdza Kardynała K. Wojtyły, ale pod jego patronatem i finansowym wsparciem, wspólnie z Papieskim Wydziałem Teologicznym w Metropolitalnym Seminarium Duchownym; poświęcone ono było problemowi „Świętości i kultu świętych w okresie patrystycznym”; wygłoszono 13 prelekcji $^{21}$, a uczestniczyło w nim 65 osób. I tym razem tematykę obrad oraz problem prelegentów, noclegów i ich utrzymania omówiła p. doc. L. Małunowiczówna kierownik Zakładu z Księdzem Kardynałem, licząc również chociaż na częściową jego obecność, on jednak ze względu na nawał obowiązków odpowiedział, że tym razem niechaj się zwróci do Rady Wydziału Papieskiego Wydziału Teologicznego, zwłaszcza do Dziekana ks. prof. Mariana Jaworskiego; faktycznie Ksiądz Kardynał był w tym czasie wyjątkowo zajęty, bo musiał wówczas przewodniczyć obradom Komisji Koordynacyjnej Synodu Prowincjalnego, podczas których miało nastąpić przyjęcie jego statutu i regulaminu; i rzeczywiście nie figuruje on na żadnej z list obecności. W dwóch zachowanych listach

19 Por. Boniecki, Kalendarium życia Karola Wojtyty, s. 463: „12-13 II 1974. Rezydencja arcybiskupów krakowskich, sympozjum patrologiczne. 13 II godz. 8.30 kaplica domowa, Msza św. koncelebrowana $z$ kazaniem na spotkaniu patrologów i archeologów".

20 Akta Zakładu. Sympozja I: sympozjum 12.

21 Por. program sympozjum (Kraków, 31 V - 2 VI 1976): ks. doc. dr J. Kudasiewicz (Kielce Seminarium Duchowne): Użycie i sens terminu „Agios” w Nowym Testamencie; ks. dr A. Kubiś (Kraków - Metropolitalne Seminarium Duchowne), Kształtowanie się pojęć „męczeństwo”, „męczennik" w okresie patrystycznym w świetle badań wspótczesnych; ks. prof. V. Saxer (Papieski Instytut Archeologii Chrześcijańskiej w Rzymie), Le culte des martyrs en Afrique du $I I^{e}$ au VI siècle [cz. 1 i 2]; prof. dr Leokadia Małunowiczówna (KUL), Nowe koncepcje świętości (confessor, asceta itp.); ks. doc. dr W. Schenk (KUL), Kult świętych w starożytności chrześcijańskiej, ks. prof. R. Jacquard (Papieski Instytut Archeologii Chrześcijańskiej w Rzymie), Le culte de Saint Piérre à Rome avant 350; doc. dr. B. Filarska (KUL), Miejsca kultu męczenników; ks. dr R. Andrzejewski (KUL), Kult relikwii według św. Ambrożego; doc. dr T. Dobrzeniecki (Warszawa - Muzeum Narodowe), Wybrane zagadnienia ikonografii świętych $w$ sztuce wczesnochrześcijańskiej [cz. 1 i 2]; dr T. Górski (Kraków - Metropolitalne Seminarium Duchowne), Martyrologia i kalendarze; ks. dr A. Bober SJ (KUL), Patrystyczna literatura hagiograficzna; mgr B. Rostkowska (WarszawaZAŚ PAN), Święci w sztuce nubijskiej. Z zagadnień kultu i ikonografii; doc. dr T. Dobrzeniecki (Warszawa - Muzeum Narodowe), Apokryfy w ikonografii świętych. 
do ks. Dziekana M. Jaworskiego (30 I i 12 IV 1976 r.) organizatorka pyta go, na jaką konkretnie pomoc może ona liczyć z jego i Wydziału strony ${ }^{22}$, bo faktycznie trzeba było m.in. zapewnić noclegi dla ponad 50 uczestników. Mimo wielu zajęć Ksiądz Kardynał znalazł jednak chwilę czasu na spotkanie z uczestnikami sympozjum przewodnicząc koncelebrze w południe na jego zakończenie i wygłaszając do nich homilię 23 .

Również w późniejszym czasie wielokrotnie, gdy brakowało pieniędzy na organizowanie kolejnych sympozjów lub wydawanie jakiejś publikacji patrystycznej przez Zakład, Pani Kierownik zwracała się o pomoc finansową, a on w miarę możliwości zawsze jej udzielał lub popierał inicjatywy Zakładu, zwłaszcza zanim w 1977 r. powstała Sekcja Patrystyczna przy Komisji Episkopatu d/s Nauki Katolickiej. Do dziś dnia przechowuje się w Zakładzie podarowane przez niego „na czarną godzinę” Zakładu dwa złote zegarki kieszonkowe i złotą papierośnicę. Gdy zaś w 1980 r. Pani kierownik Zakładu prof. L. Małunowiczówna przesłała mu po raz ostatni życzenia wielkanocne i powiadomiła o swojej śmiertelnej chorobie, on jako papież odpowiedział zaraz, na miesiąc przed jej śmiercią, następującym listem prywatnym:

\section{Droga Pani Leokadio!}

Bóg zaptać za list wielkanocny. Życzenia $w$ nim przekazane sq poparte wielkim cierpieniem - $i$ dlatego też maja szczególna dla mnie wagę. Przywotuja mi na pamięć Osobę, która zawsze tak bardzo była oddana Chrystusowi i bliźnim, a przy tym zawsze tak pogodna i petna ludzkiej serdeczności - tę Pania Leokadię, która z klasyką łączyła apostolstwo, a z życiem profesorskim duchowa konsekrację.

Będę szczególnie pamiętat o Niej w modlitwie, aby Pan dat Jej taskę każdej chwili - a jeśli taka jest Jego Wola - zachowat Ja dla nas.

$Z$ serdecznym błogosławieństwem

Jan Pawet pp II

Watykan, Niedziela Palmowa 30 marca 1980 r.

WPani

Prof. Dr Leokadia Małunowicz ${ }^{24}$

ul. Sławińskiego 8 m. 91

Lublin

22 Por. Akta Zakładu, Sympozja II: sympozjum 15.

23 Por. Boniecki, Kalendarium życia Karola Wojtyly s.701: „2 VI 1976, godz. 12.00: Seminarium Duchowne (Wydział Teologiczny), zakończenie sympozjum patrystycznego, koncelebra, kazanie".

24 Por. Chrześcijanie, red. B. Bejze, XIII, Warszawa 1984, 267. 
Gdy w 1981 r. zaczęto w Zakładzie wydawać „Vox Patrum”, otrzymaliśmy jego papieskie błogosławieństwo. Dnia 23 X 1983 r. kilku członków zespołu redakcyjnego - dr Alicja Stępniewska (sekretarz redakcji), ks. dr hab. Franciszek Drączkowski, ks. dr Augustyn Eckmann oraz ks. dr Stanisław Longosz (redaktor naczelny) - wręczyło Janowi Pawłowi II podczas specjalnej audiencji, w Sali Klementyńskiej na Watykanie, pierwsze 4 tomy „Vox Patrum” z podpisami i dedykacją: „Ojcu Świętemu Janowi Pawłowi II cztery początkowe tomy tworzącego się pierwszego polskiego periodyku patrystycznego z prośbą o błogosławieństwo - członkowie Zespołu Redakcyjnego". Ojciec Święty zainteresował się periodykiem, dłuższą chwilę rozmawiał z poszczególnymi członkami zespołu, wypytując ich o zainteresowania i kwalifikacje naukowe, a na końcu powiedział: „Błogosławię wam, wydawajcie dalej” (por. fot. 2-5) ${ }^{25}$. Warto tu też zauważyć, że jako wyraz wdzięczności za zainteresowanie się Ojca Świętego problematyką antyku chrześcijańskiego, każdy prawie tom „Vox Patrum”, jako jedyne czasopismo patrystyczne w świecie, ma w swej strukturze stały dział „Dokumenty”, w którym publikowane są wypowiedzi papieskie i Najwyższego Nauczycielskiego Urzędu Kościoła na temat Ojców Kościoła i różnych rocznic starożytności chrześcijańskiej.

Gdy w dniach 25-26 maja 1999 r. Zakład zorganizował jubileuszowe dwudniowe ogólnopolskie sympozjum nt. „Polskie studia nad antykiem chrześcijańskim" z okazji 30-lecia swego istnienia, Jan Paweł II przesłał na ręce Wielkiego Kanclerza KUL, ks. abpa Józefa Życińskiego następujący okolicznościowy telegram z życzeniami ${ }^{26}$ :

25 Por. S. Longosz, „Vox Patrum” u Ojca Świętego Jana Pawła II, VoxP 3 (1983) z. 5, 495.

${ }^{26}$ Por. VoxP 19 (1999) t. 36-37, 7-8. 


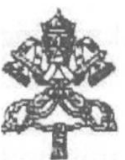

SEKRETARIAT STA N U

SEKCJA PIERWSZA . SPRAWY OGÓLNE

Watykan, 22 maja 1999 r.

\author{
Jego Ekscelencja \\ Ks. Arcybiskup Józef ŻYCIŃSKI \\ Metropolita Lubelski \\ Wielki Kanclerz \\ Katolickiego Uniwersytetu Lubelskiego \\ Lublin
}

Na ręce Księdza Arcybiskupa przesyłam Uczestnikom Sympozjum zorganizowanego dla uczczenia 30. rocznicy działalności Międzywydziałowego Zakładu Badań nad Antykiem Chrześcijańskim Katolickiego Uniwersytetu Lubelskiego wyrazy duchowej łączności i serdeczne gratulacje.

Zakład Badań nad Antykiem Chrześcijańskim jest mi bardzo drogi. Czuję się z nim związany od samego początku jego powstania. Wyrażam szczere uznanie dla tych wszystkich, którzy dali swój wkład serca i umysłu w rozwój i funkcjonowanie tej Instytucji tak wielce zasłużonej dla polskiej nauki, jak również w organizowanie ogólnopolskich sympozjów naukowych. Dziękuję Bogu i ludziom za to wielkie dzieło.

Życzę Pracownikom tej Instytucji i wszystkim polskim patrologom dalszych owocnych sukcesów w odkrywaniu cennej myśli Ojców Kościoła i umiejętnym wdrażaniu jej we współczesną teologię. Wiadomo mi, że Zakład ten, poprzez organizowane ogólnopolskie sympozja, wydawanie jedynego w Europie Srodkowej periodyku patrystycznego Vox Patrum i inne inicjatywy popularyzacyjno-naukowe przyczynił się w dużym stopniu do wzrostu i uporządkowania polskich badań nad starożytnością chrześcijańską.

Pracownikom Zakładu Badań nad Antykiem Chrześcijańskim i wszystkim polskim patrologom, na dalszy trud ich pracy naukowej z serca udzielam Apostolskiego Błogosławieństwa.

Watykan, dnia 22 maja 1999 r.

Jan Paweł II, Papież

Korzystając z okazji przesyłam Księdzu Arcybiskupowi wyrazy szacunku

Arcybiskup Giovanni B. Re Substytut 
W odpowiedzi na ten telegram, odczytany w kościele akademickim podczas Mszy Świętej koncelebrowanej w pierwszy dzień obrad 25 maja 1999 r. przez Wielkiego Kanclerza KUL ks. prof. abpa Józefa Życińskiego, uczestnicy sympozjum przesłali do Jana Pawła II następujące podziękowanie podpisane przez kierownika Zakładu - ks. dra hab. S. Longosza, kuratora patrologii ATK - ks. prof. E. Stanulę oraz prezesa Sekcji Patrystycznej i dziekana Wydziału Teologii KUL - ks. prof. J. Pałuckiego:

\section{KATOLICKI UNIWERSYTET LUBELSKI}

Międzywydziałowy Zakład Badań

nad Antykiem Chrześcijańskim

Jego Świątobliwość

Jan Paweł II

Città del Vaticano

ROMA

Uczestnicy ogólnopolskiego sympozjum patrystycznego, poświęconego polskim studiom nad starożytnością chrześcijańską, zebrani w Lublinie z okazji 30-lecia działalności Międzywydziałowego Zakładu Badań nad Antykiem Chrześcijańskim KUL, przesyłają głębokie podziękowania za otrzymane gratulacje, życzenia i Błogosławieństwo Apostolskie, dołączając wyrazy gorącej miłości i oddania oraz zapewniając o naszym czuwaniu modlitewnym w intencji Waszej Świątobliwości.

†Józef Życiński, biskup lubelski

Wielki Kanclerz KUL

Ks. Stanisław Longosz, kierownik Zakładu

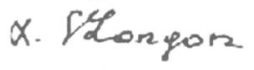

O. Emil Stanula, kurator Patrologii ATK

$$
\text { G. Emit Stamle Qs.R }
$$

Ks. Jerzy Pałucki, prezes Sekcji Patrystycznej

Lublin, 26.V.1999 r.

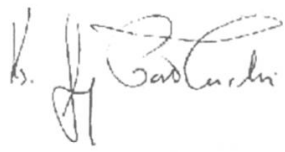




\section{SEKCJA PATRYSTYCZNA}

Drugą instytucją antyku chrześcijańskiego, na której powstanie wpłynął Ksiądz Kardynał K. Wojtyła, jest Sekcja Patrystyczna przy Komisji Episkopatu d/s Nauki Katolickiej. Nie było jej jeszcze jako autonomicznej jednostki wśród 19 sekcji, wymienianych na III Kongresie Teologów Polskich w Krakowie (21-23 IX) w 1971 roku; patrologowie skupieni byli wówczas przy Sekcji Filologicznej, a wcześniej przy Sekcji Homiletycznej. Powołania autonomicznej sekcji patrologów domagał się już, jak wspominaliśmy, ks. dr Roman Andrzejewski w 1974 r. na zjeździe badaczy antyku chrześcijańskiego w Krakowie ${ }^{27}$, potem jeszcze głośniej wołano o nią głosami ks. doc. dra hab. Wacława Hryniewicza OMI i przewodniczącego Sekcji Filologicznej - ks. mgra Władysława Wójcika na IV Kongresie Teologów Polskich (14-16 IX) w Krakowie w 1976 r., co właśnie podjął, zaakceptował i obiecał zrealizować w najbliższej przyszłości przewodniczący Komisji Episkopatu d/s Nauki Katolickiej - ks. Kardynał K. Wojtyła. O jej zorganizowanie zwrócił się do patrologów KUL-u i ATK, znanych sobie z sympozjów Zakładu Badań nad Antykiem Chrześcijańskim, którym przewodził o. dr Emil Stanula CSsR z ATK i doc. Leokadia Małunowiczówna z KUL-u. Wkrótce zaczęły się spotkania grupy ok. 10 patrologów z tych dwóch środowisk naukowych (2 XII 1976, 10 II 1977, 21 IV 1977, 30 IV 1977, 2 VI 1977, 25 VI 1977) w Warszawie lub Lublinie, którzy wypracowali jej strukturę i statut w porozumieniu z Księdzem Kardynałem. Na zebraniu organizacyjnym 25 VI 1977 roku w Warszawie postanowiono, że stan organizowania się Sekcji oraz jej prowizorycznie opracowany statut omówi w sierpniu tego roku z Księdzem Kardynałem w Krakowie ks. dr Stanisław Longosz, a w Komisji Episkopatu d/s Nauki Katolickiej w Warszawie we wrześniu - o. dr Emil Stanula CSsR.

Wreszcie na ogólnopolskim sympozjum zorganizowanym 3 XI 1977 r. przez Międzywydziałowy Zakład Badań nad Antykiem Chrześcijańskim w Bibliotece Uniwersyteckiej KUL w Lublinie ${ }^{28}$ powołano Sekcję Patrystyczną z następującym zarządem: prezes - ks. dr Stanisław Longosz z Tarnowa, wiceprezes - ks. dr Marek Starowieyski z Warszawy, sekretarz - o. dr Emil Stanula CSsR z ATK i skarbnik ks. dr Wincenty Myszor z ATK. Do zarządu dokooptowano p. doc. L. Małunowiczównę jako stałego przedstawiciela Zakładu Antyku Chrześcijańskiego KUL oraz p. doc. B. Filarską jako stałego przedstawiciela archeologii chrześcijańskiej, którą włączono do Sekcji Patrystycznej dopóki się nie usamodzielni ${ }^{29}$.

27 Por. wyżej, nota 20.

28 Por. tematykę sympozjum (3-4 XI 1977): C. Mondésert SJ, Apologétique chrétienne: conceptions anciennes et modernes; tenże, Les martyrs chrétiens à Lyon en 1977; tenże, La Collection „Sources Chrétiennes”; N. Van der Vorst-Zeegers, Les premiers apologistes grécs et les poètes paiens: polémique ou conciliation; taż, Les rabbiniques de l'exégèse de la création chez Théophile d'Antioche; 3 XI godz. 17.00: Ukonstytuowanie sie Sekcji Patrystycznej.

29 Cała dokumentacja z konstytuowania się Sekcji Patrystycznej, w: Akta Sekcji Patrystycznej 
Wyniki wyborów i ukonstytuowania się zarządu Sekcji Patrystycznej zaprezentował Księdzu Kardynałowi 23 I 1978 r. jej prezes ks. dr S. Longosz. Ksiądz Kardynał przyjął tę wiadomość z ogromną radością i zadowoleniem oraz polecił nowemu zarządowi Sekcji: 1. przygotować specjalne pismo do Komisji Episkopatu d/s Nauki Katolickiej z prośbą o formalne erygowanie Sekcji Patrystycznej; 2. opracować ankietę odnośnie danych personalnych i kwalifikacji naukowych nauczycieli dyscyplin patrystycznych jako członków Sekcji, którą on obiecał ze swym specjalnym polecającym pismem przesłać do wszystkich rektorów lub przełożonych polskich Wyższych Seminariów Duchownych; 3 . w niedługim czasie przygotować ogólnopolskie sympozjum i spotkanie wszystkich członków Sekcji Patrystycznej, na którym poinformowano by ich o powinnościach wobec niej. Gdy 15 II 1978 r. odbywało się w arcybiskupim pałacu w Krakowie posiedzenie Komisji Episkopatu d/s Nauki Katolickiej, Ksiądz Kardynał zdając sprawozdanie z jej pięcioletniej działalności (19731978) poinformował również o powstaniu Sekcji Patrystycznej, którą można dołączyć do wcześniejszych 19 Sekcji ${ }^{30}$.

W krótkim czasie najpierw przygotowano postulowaną ankietę (patrz s. 89), którą prezes Sekcji dostarczył Księdzu Kardynałowi, a następnie podanie do Komisji Episkopatu d/s Nauki Katolickiej z prośbą o formalne erygowanie Sekcji Patrystycznej wraz z dołączonym Regulaminem Sekcji i protokołem zebrania wyborczego, które Prezes przekazał 23 IV 1978 r. Przewodniczącemu Komisji (s. 90).

Niedługo potem zarząd Sekcji Patrystycznej na zebraniu 18 maja 1978 r. postanowił, że jej pierwsze sympozjum, zorganizowane wspólnie z Międzywydziałowym Zakładem Badań nad Antykiem Chrześcijańskim KUL i Katedrami Patrologii ATK, jako swego rodzaju pierwszy kongres patrologów polskich, odbędzie się 19-21 października 1978 r. w Tarnowie na temat: „Modlitwa starożytnych chrześcijan", a na jego otwarcie poprosi się przewodniczącego Komisji Episkopatu d/s Nauki Katolickiej - Księdza Kardynała K. Wojtyłę, któremu wcześniej prześle się szczegółowy program konferencji ${ }^{31}$. Tymczasem oczekiwano na jego odpowiedź odnośnie zatwierdzenia Sekcji Patrystycznej.

(przekazywane każdorazowemu prezesowi), opublikowana w artykule: S. Longosz, 5-lecie Sekcji Patrystycznej, VoxP 2 (1982) z. 2, 121-135.

30 Por. Boniecki, Kalendarium życia Karola Wojtyty, s. 651-652.

${ }^{31}$ Por. tematykę sympozjum (Tarnów, 19-21 X 1978): ks. dr H. Wójtowicz (KUL), Modlitwa w religii greckiej; ks. dr W. Myszor (ATK), Problem modlitwy w gnostyckich tekstach z NagHammadi; prof. dr hab. A. Sadurska (UW), ,Pietas” w sztuce rzymskiej; ks. dr R. Andrzejewski (KUL), Modlitewny stosunek Cycerona do bogów; ks. dr S. Longosz (Tarnów), Najstarsze formuly modlitwy rzymskiej w przekazie Tytusa Liwiusza; ks. dr A. Paciorek (Tarnów), Troska o zmartych w modlitwie i obrzędach starożytnych Greków; prof. dr hab. A. Sadurska (UW), Dzień Święty $w$ kalendarzu chrześcijańskim i jego geneza rzymsko-orientalna. Ikonografia dni tygodnia. Kalendarze użytkowe; ks. dr A. Bober SJ (KUL), Modlitwa patrystyczna. Przegląd bibliograficznokrytyczny; ks. dr M. Bednarz (Tarnów), Modlitwy Jezusa w Łukaszowym opisie Męki; dr S. 
Pod koniec czerwca 1978 r. Ksiądz Kardynał przesłał oczekiwaną odpowiedź na ręce prezesa Sekcji Patrystycznej zapowiadając, że na najbliższym, tj. jesiennym posiedzeniu Komisji Episkopatu d/s Nauki Katolickiej przedstawi wniosek o zatwierdzenie Sekcji Patrystycznej, który następnie zostanie przedłożony Konferencji Plenarnej Episkopatu Polski (s. 91, 92).

Potem już wiemy, jak wyglądały dalsze kontakty Księdza Kardynała K. Wojtyły z Sekcją Patrystyczną; przyjął zaproszenie i obiecał osobiście otworzyć jej pierwsze sympozjum w Tarnowie. Na dwa tygodnie jednak przed tym sympozjum Ksiądz Kardynał musiał wyjechać na konklawe do Rzymu. Wcześniej jednak przesłał na ręce prezesa Sekcji Patrystycznej - ks. dra S. Longosza powyższy list usprawiedliwiający swoją nieobecność i niemożliwość otwarcia sympozjum w Tarnowie ${ }^{32}$.

Kalinkowski (ATK), Czas i miejsce modlitwy starochrześcijańskiej; A. Malinowski (KUL), Modlitwy męczenników; prof. V. Grossi OSA (Instytut Patrystyczny, Rzym), Il contesto battesimale dell'Oratio dominica nei commenti di Tertulliano, Cipriano, Agostino; ks. dr B. Częsz (Poznań), Ekumeniczny charakter modlitwy u św. Ireneusza; ks. dr L. Gładyszewski (Gniezno), Modlitewne hymny św. Ambrożego; ks. dr E. Staniek (Kraków), Komentarz do Pisma Świętego jedna z form modlitwy patrystycznej; ks. dr E. Stanula CSsR (AT K), Modlitwa w wykładzie teologicznym św. Hilarego z Poitiers; prof. T. Špidlik SJ (Instytut Orientalny, Rzym), La Prière en l'Église d'Orient; ks. dr F. Drączkowski (KUL), Znaczenie słów Klemensa Aleksandryjskiego: „Modlitwa jest rozmowa z Bogiem" w ich kontekście bliższym i dalszym; ks. dr hab. W. Kania (Tarnów), Pierwszy naukowy traktat o modlitwie: Orygenesa „Peri euches”; ks. dr Sz. Pieszczoch (Żydowo k. Gniezna), Modlitewne zasady Ewagriusza Pontyńskiego; ks. dr J. Sobkowiak (Łódź), Modlitwa i doskonatość wg Pseudo-Makarego z Egiptu; ks. mgr W. Wójcik (Kielce), Znaczenie Modlitwy Pańskiej w nauce św. Grzegorza z Nyssy; ks. mgr Jerzy Woźniak CM (Żmigród), Problematyka modlitwy u Afrahata Syryjczyka; Starożytna liturgia eucharystyczna - koncelebra w Bazylice Katedralnej; Inscenizacja Akathistos w auli seminarium (klerycy); ks. dr B. Margański (Tarnów), Kształtowanie się modlitwy liturgicznej w okresie Ojców Kościoła; ks. dr hab. W. Eborowicz (Pelplin) Funkcja modlitwy w homiliach św. Augustyna; ks. dr E. Łomnicki (Tarnów) Modlitwa eucharystyczna w przekazie św. Justyna; ks. mgr K. Obrycki (ATK), Modlitwa za zmartych u Tertuliana; dr J. Wojtczak (ATK), Quid F. Lactantius de oratione senserit?; mgr B. Wronikowska (KUL), Problem motywu oranta w sztuce wczesnochrześcijańskiej; prof. dr L. Małunowiczówna (KUL), Modlitwa prywatna starożytnych chrześcijan; ks. dr S. Longosz (Tarnów), Znak Krzyża św. w życiu starożytnych chrześcijan; ks. dr E. Stanula CSsR (ATK), Uwagi na temat znaczenia słowa „medytacja” w komentarzach biblijnych św. Hilarego z Poitiers; ks. dr M. Starowieyski (Warszawa), Modlitwa u Ojców Pustyni; ks. dr J. Górny (Olsztyn), Modlitwa w życiu wspólnot monastycznych w świetle pism św. Hieronima; ks. dr J. Śrutwa (Lublin), Problem modlitwy i pracy w monastycyzmie afrykańskim na przełomie IV $/$ wieku; ks. dr E. Stanula (ATK), Podsumowanie sympozjum; ks. dr S. Longosz (prezes Sekcji), Dyskusja nad problemami dydaktyki dyscyplin patrystycznych, propozycje, wnioski. Akta sympozjum wydano w całości w: TST 8 (1891).

32 Oryginał listu w aktach Kurii Diecezjalnej w Tarnowie. Czytelna kopia:

Kraków, 2 października 1978 r.

Czcigodny Księże Profesorze

Pragnę serdecznie podziękować za zaproszenie mnie do wzięcia udziatu w sympozjum patrystycznym na temat: „, Modlitwa starożytnych chrześcijan”, organizowanym przez Sekcję Patrystyczna przy Komisji Episkopatu Polski d/s Nauki, Międzywydziałowy Zakład Badan nad Antykiem Chrześcijańskim oraz Katedrę i Zakład Patrologii ATK. Niestety w sympozjum tym nie wezme 
Gdy obradowało pierwsze sekcyjne sympozjum w Tarnowie (19-21 X) Ksiądz Kardynał K. Wojtyła był od trzech dni papieżem Janem Pawłem II. Podczas obrad z ogromnym zainteresowaniem nasłuchiwaliśmy wszelkich informacji napływających z Rzymu, a dzielił się nimi szczodrze świeżo przybyły z Rzymu prelegent - o. prof. Vittorino Grossi OSA, który był na Placu św. Piotra, gdy ogłaszano: „Habemus papam”. Uczestnicy sympozjum przesłali do Rzymu telegram o następującej treści:

\title{
Jego Swiątobliwość \\ JAN PAWEE II \\ Città del Vaticano ROMA
}

Uczestnicy Sympozjum Patrystycznego, poświęconego modlitwie Ojców Kościoła, zebrani $\mathrm{w}$ Tarnowie, przesyłają wraz $\mathrm{z}$ modlitwami wyrazy hołdu, uczucia radości i oddania, prosząc o błogosławieństwo dla dalszych prac Sekcji Patrystycznej, powstałej pod patronatem Waszej Swiątobliwości.

Tarnów, 20. X. 78.

\author{
$\dagger$ Jerzy Ablewicz, biskup tarnowski \\ Ks. Stanisław Longosz, prezes Sekcji Patrystycznej \\ O. Emil Stanula, ATK \\ Barbara Filarska, KUL
}

\begin{abstract}
udziału ze wzglądów dobrze znanych: niespodziewana śmierć Ojca św. Jana Pawła I i mające się odbyć konklawe.

Jeżeli idzie o samo sympozjum, to pragnę wyrazić me głębokie zadowolenie z tematu obrad. Problem modlitwy jest zawsze bardzo ważny w życiu Kościoła. Dzisiaj nabiera on szczególniejszej aktualności w związku z jej coraz większym niedocenianiem przez wspótczesnych ludzi. Sądzę, że pogtębiona refleksja nad modlitwą starożytnych chrześcijan przez polskich badaczy okresu patrystycznego może stanowić cenny wkład do jej dowartościowania w świadomości Ludu Bożego.

Jako Przewodniczący Komisji Episkopatu d/s Nauki Katolickiej wyrażam radość, że świeżo ukonstytuowana Sekcja Patrystyczna uczestniczy czynnie w zorganizowaniu sympozjum. Wszyscy odczuwaliśmy potrzebę jej istnienia i jestem przekonany, ̇̇e w przyszłości dobrze przystuży się ona do rozwoju studiów patrystycznych na terenie całego kraju, włączając w zakres swojej działalności dydaktyczno-naukowej wszystkich wykładowców i profesorów patrologii Uczelni Katolickich oraz Wyższych Seminariów Duchownych tak diecezjalnych jak i zakonnych.

Prosze przyjąć szczere życzenia błogostawieństwa Bożego i owocnych obrad.

Przewielebny

Ks. prof. Stanisław LONGOSZ

Przewodniczący Sekcji Patrystycznej

33-100 Tarnów

ul. Kapitulna 4

+ Karol Wojtyła

Przewodniczący Komisji Episkopatu d/s Nauki Katolickiej
\end{abstract}


Ankieta Personalna członka Sekcji Patrystycznej:

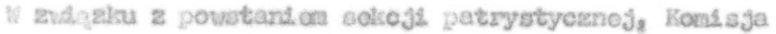

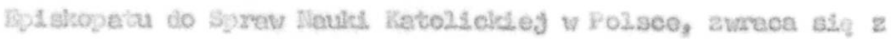

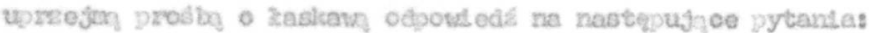

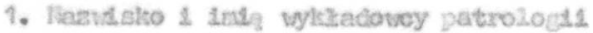

2. Stucida sjecjaltzacyJnes ................

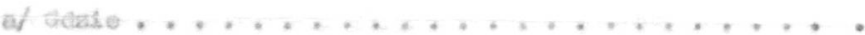

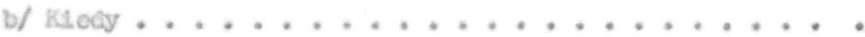

c/ Jakn etyscypisng studioved

d stoplent nothovy ..................

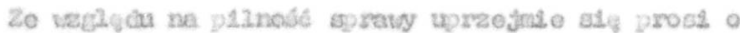
przeszanse wyparntonos anksety do plervezogo marea 1978 s. na

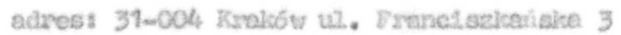

KOMISIA EPISKOPATU DO SPRAW

NAUKI MATOLICKIEJ

Kraków, enia 29 stycznia $1978 r$.

\section{Czelgodny Księże Rektorze,}

Załączając niniejsz̨̨ ankietę dla wykzadających patrologlę w Vyzszych Seminariach Duchovaych grosze - przeikazanie jej zainteresowanemu profesorow1.

$30 / 178$ wysłano

do wszystkich Księży Rektorów Wyższych Seminariow Duchownych 7 biecezjalnych i Zakonnych /wg wykazu z akt/ 
Konisja Episikopetu

do Spraw Iavill Ketolicklej $v$ Polsce $x$

VI: dniu 3 listopede 1977 rolsu podcras sympozjum newkovego

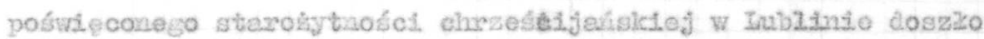
do ukonstytuowanta sle sekcj1 petrystyomej 1 vryoru zarmgău. V alczed zaxządu weszli:

$$
\begin{aligned}
& \text { Ks. Dx Stentazaw Jongosz - presos } \\
& \text { Ks. Dr liexeic stercouleysikt - wieeprozes } \\
& \text { Ks. Dr Mul Stanule - selaretarz }
\end{aligned}
$$

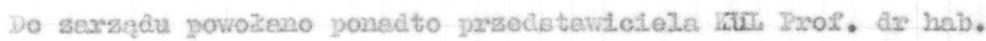

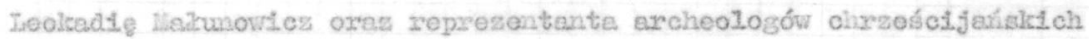
Doc. dre hob. Berbere Milarslez.

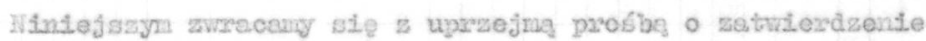
proponownego regulaminu powstejaces Selcaj1/p. galkagandk 1/,

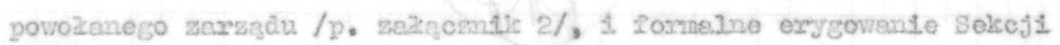

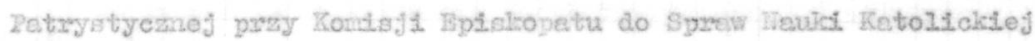
w Polsce.

Wargawe 23 kwtetnte $1978 x$.

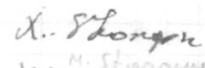
xin.itarowieyn.

Zakącond1:1:

1. Regulamin Sekej1

2. Rxotok6́z z zobranta wyborezogo

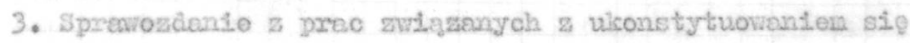
Sekcji Patryetycanej 
KOMISJA EPISKOPATU

DO SPRAW

NAUKI KATOLICKIEJ

Kraków, 23 czerwca 1978 r.

Czcigodny Księże Profesorze,

W odpowiedzi $\mathrm{n}$ a list z 23. IV.1978 r. powiadamiający Komisję Episkopatu d/s Nauki Katolickiej o ukonstytuowaniu się Sekcji Patrystycznej w ramach ogólnej organizacji nauki katolickiej w Polsce pragnę wyrazić, jako Przewodniczący tejze Komisji, swoja radość $z$ tego powodu. Istnienie Sekcji Patrystycznej było bowiem juź od dłuższego czasu przedmiotem zainteresowania Komisji d/s Nauki, czemu dałem wyraz w czasie obrad ostatniego Kongresu Teologów Polskich w Krakowie. Pragnę zarazem poinformować Księdza Doktora, że na najbliższym, tzn. Jesiennym posiedzeniu Komisji d/s Nauki przedstawię wniosek o zatwierdzenie Sekcji Patrystycznej, który następnie zostanie przedłożony Konferencji Plenarnej Episkopatu. Załączona dokumentacja z całą pewnością odda Komisji d/s Nauki dużą usługę przy załatwianiu wszystkich formalności. Już teraz jednak sygnalizuję, że jeżeli idzie o przedstawiony "Projekt Regulaminu Sekcji Patrystycznej" to będzie on musiał byc dostosowany do ogolnego Regulaminu obowiązującego wszystkie Sekcje, ktory nota bene zostanie w najblizszej przyszłości znowelizowany, między innymi w oparciu o wypowiedzi róznych Przewodniczących Sekcji. Stąd do niniejszego listu załączam aktualny Regulamin dla zgłoszenia ewentualnych uwag równleż ze strony patrologów. Uwagi te należy przesłać na adres Komisji d/s Nauki w terminie mozllwie najkrótszym. Z kapłańskim pozdrowieniem

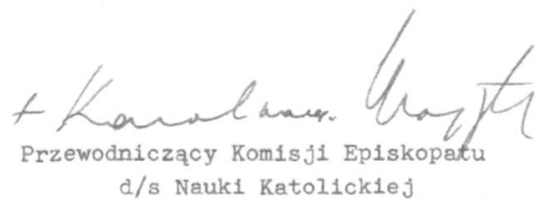

Przewielebny

Ks, dr Stanisław LONGOSZ

33-100 Tarnów

ul. Kapitulna 4 


\section{METROPOIITA KRAKOWSKI}

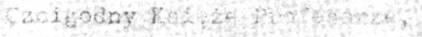

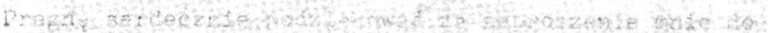

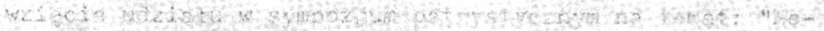

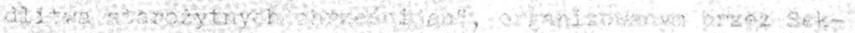

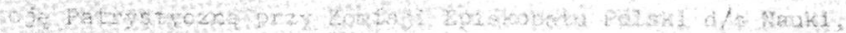

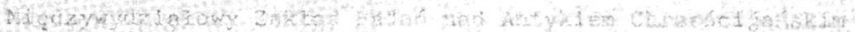
KuL

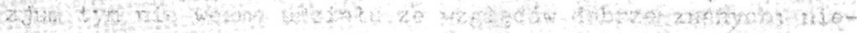

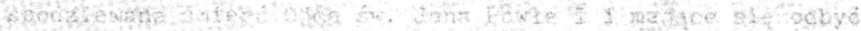
Ager hotive.

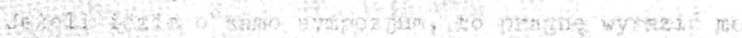

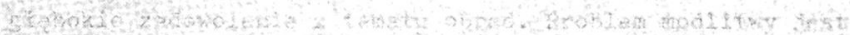

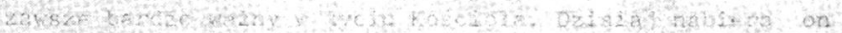

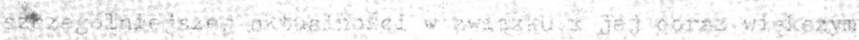

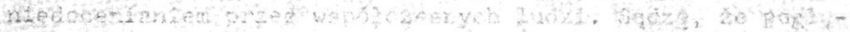

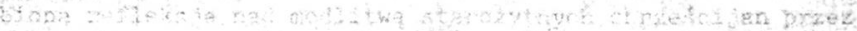

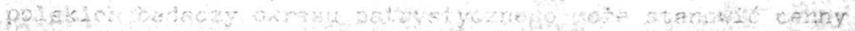

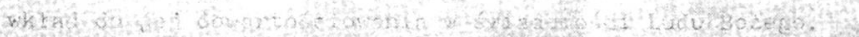

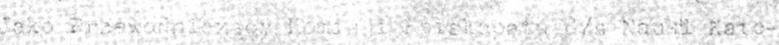

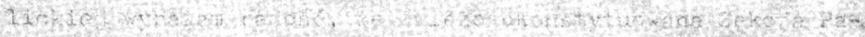
tryaty 24 .

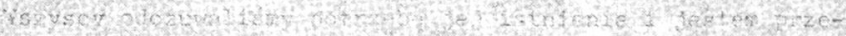

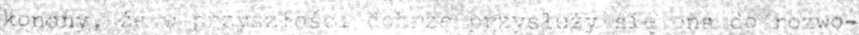

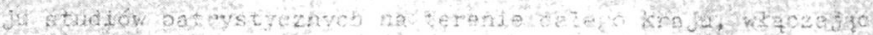

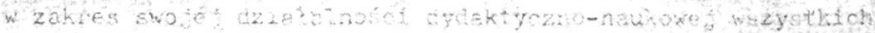

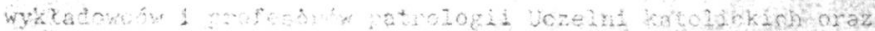

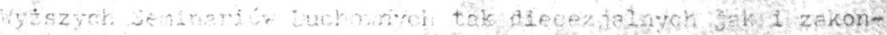
r.yok.

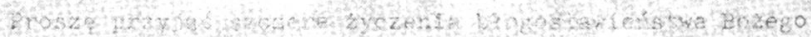
Howoenow otrer

Przfulabieky

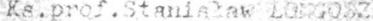

Przewodniczzey Sekidi Peatrystarcone

33-100 mann w

ai.r.ajituzna

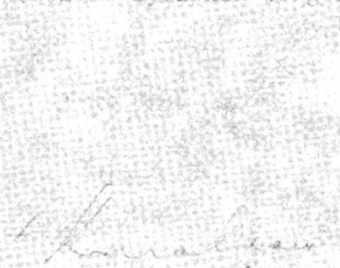

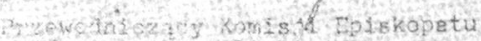
Q7. Natrit Katolickies 
Niedługo potem ks. biskup ordynariusz tarnowski Jerzy Ablewicz otrzymał z Watykanu następującą odpowiedź i podziękowanie:

\section{BP JERZY ABLEWICZ}

\section{ul. Dzierżyńskiego 9}

\section{Tarnów}

Ojciec święty Jan Paweł II wyraża uczucie wdzięczności za pamięć, oddanie i modlitwy uczestników sympozjum patrystycznego w Tarnowie, a ich mozolną pracę $w$ odczytywaniu wciąż na nowo myśli Ojców Kościoła i przybliżanie jej współczesnemu człowiekowi, z serca błogosławi.

CARDINALE VILLOT

Città del Vaticano

Wszystkie powyższe organizacyjne zasługi Księdza Kardynała K. Wojtyły wobec Zakładu Antyku Chrześcijańskiego KUL i Sekcji Patrystycznej podsumowała tuż przed swoją śmiercią jego wdzięczna admiratorka p. prof. Leokadia Małunowiczówna w słowach: „Kard. Wojtyła patronował trzem sympozjom antyku chrześcijańskiego w Krakowie. Udzielał też pomocy finansowej dla realizowania innych spotkań i inicjatyw naukowych podejmowanych przez Zakład. Wiadomo, że na skutek trudnej sytuacji finansowej KUL dotacje zakładów są bardzo niskie. Nieraz więc wysyłałam do Krakowa SOS i zawsze nadchodził ratunek. Wyrazem troski kard. Wojtyły o poziom nauczania patrologii w Polsce była między innymi ankieta rozesłana przez niego do wszystkich seminariów duchownych, by na jej podstawie można było ustalić stan faktyczny i wnioski co do polepszenia sytuacji w dydaktyce tej dyscypliny. Kardynał chciał, by powstała osobna Sekcja Patrologów wśród profesorów seminariów i innych zakładów naukowych. Miał uczestniczyć w sympozjum na temat modlitwy starożytnych chrześcijan, zorganizowanym w Tarnowie (dzięki szczodrobliwości ks. bpa J. Ablewicza) przez Sekcję Patrologów, Zakład Badań nad Antykiem Chrześcijańskim KUL i Katedrę Patrologii ATK (19-21 X). Przysłał na ręce ks. dra S. Longosza, prezesa sekcji, list zawiadamiający, że nie będzie mógł przybyć z powodu konklawe, dołączył ciepłe słowa dla uczestników i uznanie dla nowo powstałej sekcji. Z mieszanymi uczuciami - radości i smutku - przeżyłam wybór «wuja Karola» na papieża. «Obiit Carolus, natus est Joannes Paulus II». Miło było słyszeć z ust przygodnych rozmówców rzymskich wyrazy podziękowania Polsce za tak wspaniały dar złożony Kościołowi 
w osobie nowego Papieża czy też zapewnienia, że są tak bardzo szczęśliwi z wyboru kard. Wojtyły"33.

Po śmierci Jana Pawła II pracownicy Międzywydziałowego Zakładu Badań nad Antykiem Chrześcijańskim wpisali do wystawionej na KUL-u Księgi Kondolencyjnej następujące słowa wdzięczności:

„Ojcze Święty, brak nam będzie Ciebie. Dziękujemy Ci za praktyczne wcielanie soborowego hasła powrotu do źródeł: za wspieranie działalności Polskiej Sekcji Patrystycznej, Międzywydziałowego Zakładu Badań nad Antykiem Chrześcijańskim KUL i jego periodyku «Vox Patrum».

Ks. dr hab. Stanisław Longosz, prof. KUL Dr Alicja Stępniewska Ks. mgr Józef Figiel".

\section{INSTYTUT PATRYSTYCZNY W TARNOWIE}

Trzecią wreszcie, wspomnianą na wstępie, instytucją antyku chrześcijańskiego, którą Ksiądz Kardynał Karol Wojtyła planował powołać, był Instytut Patrystyczny w Tarnowie. Jako przewodniczący Komisji Episkopatu d/s Nauki Katolickiej czuł się zobowiązany do przeprowadzenia reformy polskich studiów teologicznych, a zamierzał to uczynić na wzór rzymski w formie instytutów. Reformę tę postanowił przeprowadzić najpierw w podległym sobie Papieskim Fakultecie Teologicznym w Krakowie, planując w należących do niego Wyższych Seminariach Duchownych utworzyć, stosownie do panujących w nich od lat tradycji naukowych, specjalistyczne instytuty: w Częstochowie Instytut Eklezjologiczno-Mariologiczny, w Katowicach Instytut Duszpasterski, w Kielcach Instytut Homiletyczny, a w Tarnowie Instytut Patrystyczny ${ }^{34}$; nadzór administracyjno-naukowy pełniłby nad nimi dziekan krakowskiego Fakultetu Teologicznego, one zaś byłyby utrzymywane przez miejscowe diecezje. Do próby zrealizowania tej myśli Ksiądz Kardynał przekonał najpierw księdza biskupa

33 Małunowiczówna, „Wuj” Karol, s. 18-19.

34 Por. Przemówienie do Rady Papieskiego Wydziału Teologicznego (I Pielgrzymka do Polski, 9 VI 1979) 2, w: Jan Paweł II, Pielgrzymki do Ojczyzny. Przemówienia - homilie, Kraków 2005, 181: „Wydział zgodnie ze swoim charakterem i statutem prowadził i prowadzi nadal również studia w zakresie tak zwanego cyclus specialisationis, przygotowujące do licencjatu i doktoratu. Studia te prowadzone są przede wszystkim w Krakowie. Prócz tego jednak została już zawarta umowa z Ordynariuszem Tarnowskim o powołaniu specjalistycznego Instytutu Patrologii w Tarnowie. Specjalistyczny też profil posiada wcześniej uzgodniony z Ordynariuszem Częstochowskim Instytut Eklezjologiczno-Mariologiczny w Częstochowie. Jeszcze też za mojego urzędowania została wdrożona sprawa Instytutu Pastoralnego w Katowicach". 
Jerzego Ablewicza, ordynariusza w Tarnowie, gdzie, jak mu zapewne było wiadomo, żywe były od lat tradycje patrystyczne. To z tej diecezji pochodził inicjator znanej serii patrystycznej „Pisma Ojców Kościoła” - J. Sajdak, stąd tłumacz pism katechetycznych św. Augustyna - ks. W. Budzik, stąd wielki popularyzator i tłumacz pism Ojców Kościoła - ks. J. Czuj, stąd wielki filolog i tłumacz wielu pism greckich autorów wczesnochrześcijańskich - T. Sinko, stąd działający wówczas w Tarnowie badacz i thumacz wielu pism patrystycznych, w tym także syryjskich - ks. W. Kania, a w Warszawie na ATK twórca znanej serii „Pisma Starochrześcijańskich Pisarzy” - redemptorysta ks. E. Stanula, i stąd znany mu dobrze z Rzymu niewykorzystany dotąd pierwszy polski doktor nauk patrystycznych (1976) po Instytucie Patrystycznym „Augustinianum” ks. S. Longosz, który po powrocie pracował jako wikariusz przy bazylice katedralnej w Tarnowie. Ksiądz Biskup J. Ablewicz jesienią 1977 r. przedstawił ogólnie pomysł założenia Instytutu Patrystycznego w Tarnowie najpierw na jednej z konferencji profesorów Wyższego Seminarium Duchownego (= Instytutu Teologicznego), informując, że tego rodzaju agregowany do Fakultetu Teologicznego w Krakowie Instytut działałby na prawach papieskich z możliwością nadawania akademickich stopni licencjatu i doktoratu. Wybór kierunku patrystycznego jest podyktowany sytuacją dzisiejszego Kościoła, bardzo zbliżoną do sytuacji Kościoła starożytnego, oraz ogólną posoborową tendencją powrotu do źródeł i ożywienia nimi duchowości kapłanów. Obok więc aspektu ściśle naukowego miałby on profil duszpasterski. Ojców Kościoła należałoby więcej uwzględniać w nauczaniu teologii dogmatycznej i moralnej, w homiletyce, w katolickiej nauce społecznej, w egzegezie Pisma św. i ascetyce, oraz nauczać kleryków, jak, gdzie i kiedy winni oni korzystać z nauki Ojców Kościoła. Propozycję tę profesorowie przyjęli na ogół krytycznie i bez entuzjazmu.

Ksiądz Biskup jednak dalej kontynuował realizację swego zamiaru. Na bezpośredniego organizatora przyszłego Instytutu powołał (ustnie) ks. S. Longosza, którego wprowadził w swoje plany i zlecił mu przygotowanie (po polsku i po łacinie) projektu statutów tego rodzaju Instytutu, z uwzględnieniem statutów krakowskiego Fakultetu Teologicznego i należącego doń Instytutu Liturgicznego, statutów analogicznych instytutów rzymskich na prawie papieskim, zwłaszcza Instytutu Patrystycznego „Augustinianum”, a przede wszystkim niedawno opublikowanego (31 X 1977) przez Kongregację d/s Wychowania Katolickiego przygotowanego do dyskusji projektu nowej Konstytucji Apostolskiej o kościelnych studiach akademickich (Notanda - Schema novae Constitutionis Apostolicae de studiis academicis ecclesiasticis et Ordinationum S. Congregationis pro Institutione Catholica); miał on także nawiązać kontakty z polskimi patrologami (był wówczas prezesem Sekcji Patrystycznej), którzy zechcieliby współpracować z powstającym Instytutem, zacząć gromadzić specjalistyczną bibliotekę patrystyczną przez sprowadzenie podstawowych serii (uzupełnić zdekompletowaną Patrologię Migne'a, sprowadzić Corpus Christia- 
norum i Sources Chrétiennes) i czasopism („Augustinianum”, „Vigiliae Christianae”, „Vetera Christianorum”, „Rivista di Archeologia Cristiana” i inne) patrystycznych, oraz zorganizować w jednej z większych sal Wyższego Seminarium Duchownego lektorium patrystyczne (Patristicum); na to wszystko miał przyrzeczone poparcie Księdza Biskupa i obiecane pieniądze.

W niedługim czasie ks. Longosz przygotował pierwszy projekt statutów Instytutu, krótką historię Instytutu Filozoficzno-Teologicznego (WSD) w Tarnowie, listę profesorów (Collegium professorum), wykaz nauczanych dyscyplin oraz podzielony na poszczególne semestry wykaz przedmiotów obowiązkowych do licencjatu (Disciplinae docendae), a także zamówił odpowiednie serie i czasopisma patrystyczne oraz wyposażenie przyszłego lektorium. Pierwsza merytoryczna dyskusja nad projektem statutów Instytutu odbyła się w obecności księdza Biskupa 21 II 1978 r. podczas konferencji profesorów Seminarium Duchownego w Tarnowie. Podczas dyskusji nad projektem zasugerowano m.in. podkreślenie w nim większej autonomiczności Instytutu wobec Fakultetu Teologicznego oraz większe uwzględnienie w nim polskiego i tarnowskiego środowiska, a także większe uwypuklenie profilu duszpasterskiego. Ustalono, że Instytut będzie agregowany do Fakultetu Teologicznego. Dla szczegółowszego jednak dopracowania projektu statutów powołano za sugestią Księdza Biskupa specjalną komisją, w skład której weszli: ks. dr S. Longosz, ks. dr M. Bednarz, ks. dr hab. J. Dudziak, ks. dr E. Krężel, ks. dr hab. W. Kania, ks. dr K. Kupiec, ks. dr E. Łomnicki, ks. dr B. Margański i ks. dr A. Paciorek. Komisja ta zbierała się parę razy (po raz pierwszy już 28 II 1978 r.) w cotygodniowych odstępach i dopracowywała szczegółowo poszczególne części statutów, w czym brał również czynny udział ks. Biskup. Przygotowany zaś ostatecznie projekt statutów wraz z ustalonym wykazem profesorów i nauczanych dyscyplin, zatwierdzony przez Księdza Biskupa, miał być przekazany Kongregacji d/s Wychowania Katolickiego przez Księdza Kardynała K. Wojtyłę w najbliższym czasie, sam Instytut natomiast, jeśli wszystkie sprawy zdąży się załatwić, miał rozpocząć swoją działalność w październiku 1979 roku.

Ksiądz Kardynał K. Wojtyła zostawszy papieżem czuł się nadal odpowiedzialny za realizację projektu powołania w Tarnowie Instytutu Patrystycznego w ramach Papieskiego Wydziału Teologicznego w Krakowie, gdy w lutym 1979 r. ks. dr S. Longosz znalazł się w Rzymie w poszukiwaniu książek dla biblioteki organizowanego Instytutu został zaproszony do koncelebry (z papieżem i sekretarzem ks. dr. S. Dziwiszem) w prywatnej kaplicy papieskiej (por. fot. 6-7), a później na śniadanie, podczas którego Jan Paweł II wypytywał o szczegóły konstytuowania się Instytutu, na którego księgozbiór podarował milion lirów włoskich i udzielił Apostolskiego Błogosławieństwa.

Instytut według proponowanych statutów miał być agregowany do Papieskiego Fakultetu Teologicznego jako jego sekcja specjalizacji w nauce Ojców Kościoła; miał mieć charakter naukowo-pastoralny i znajdować się pod 


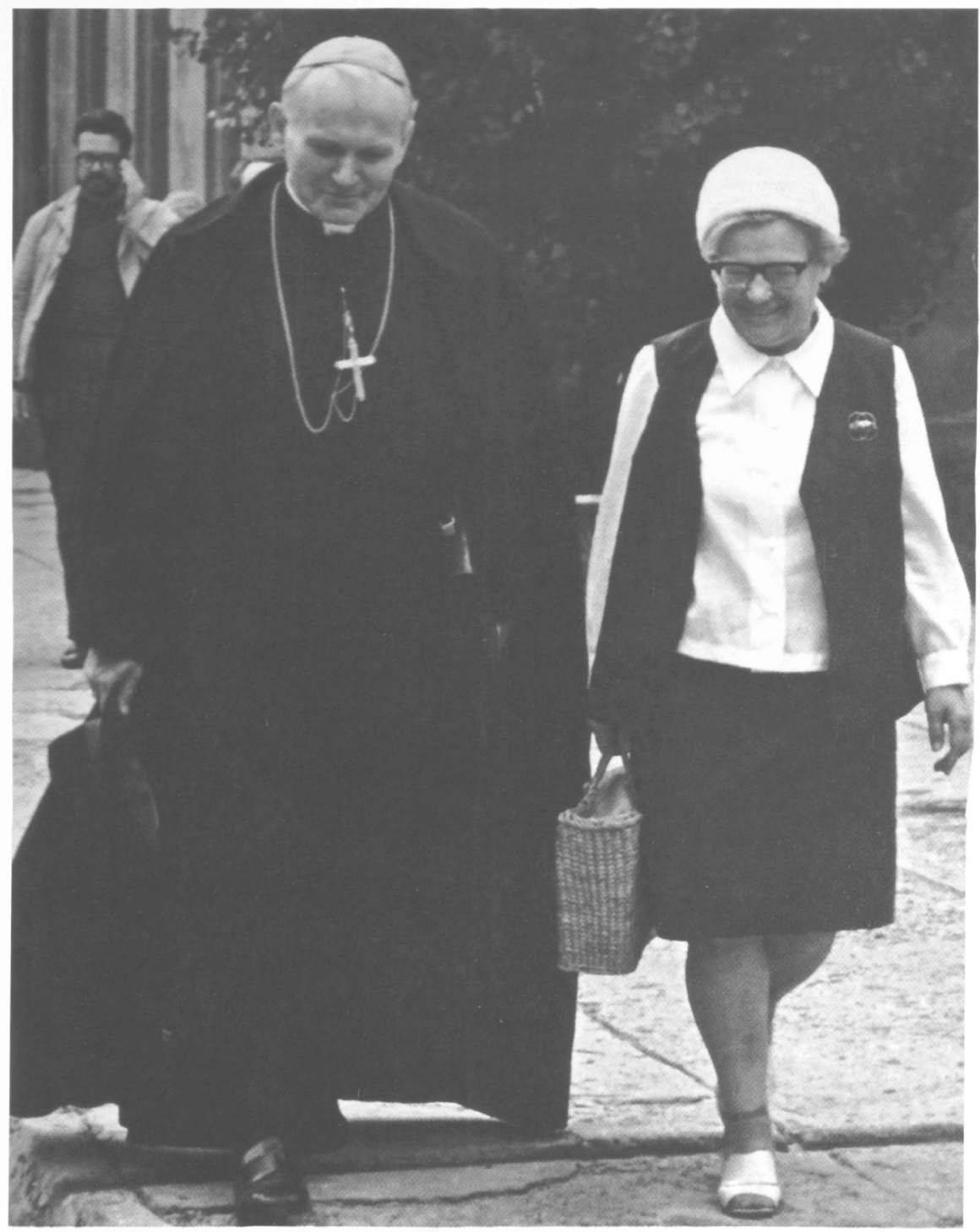

Fot. 1. Ksiądz Kardynał K. Wojtyła z prof. L. Małunowiczówną na KUL-u 


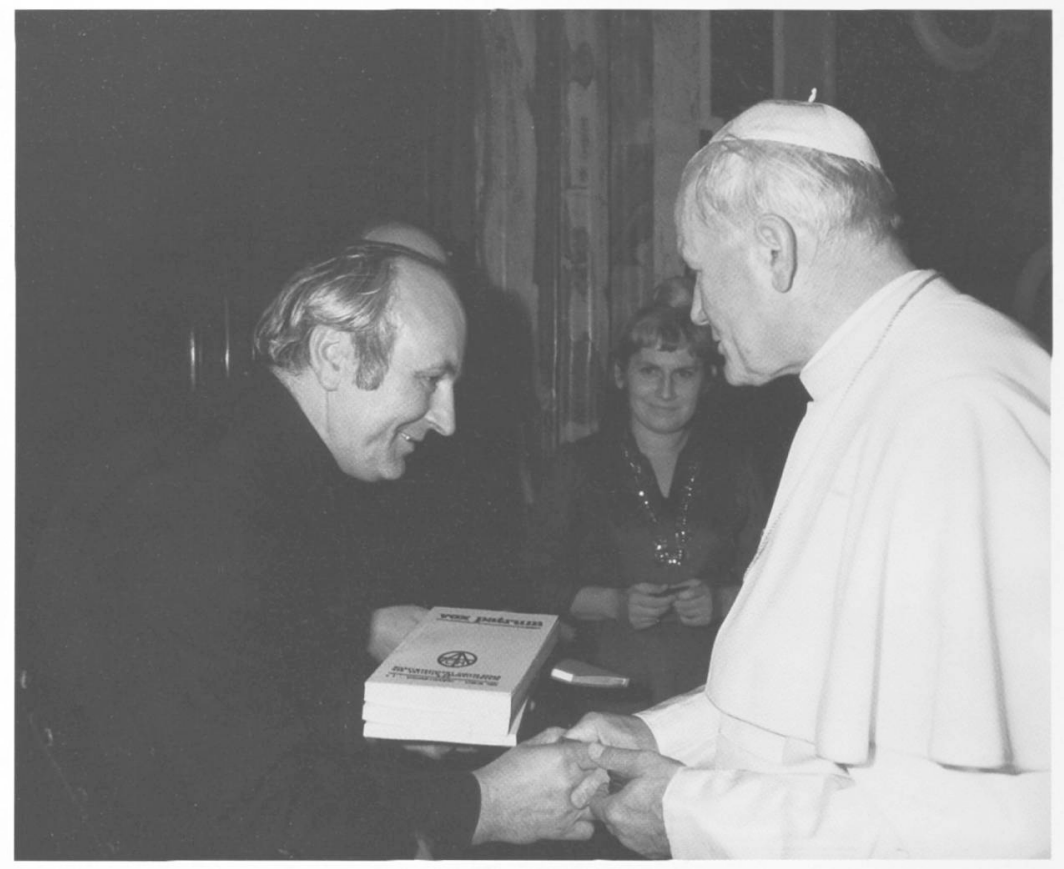

Fot. 2. Pracownicy Redakcji ks. S. Longosz i A. Stępniewska wręczają „Vox Patrum” Ojcu Świętemu

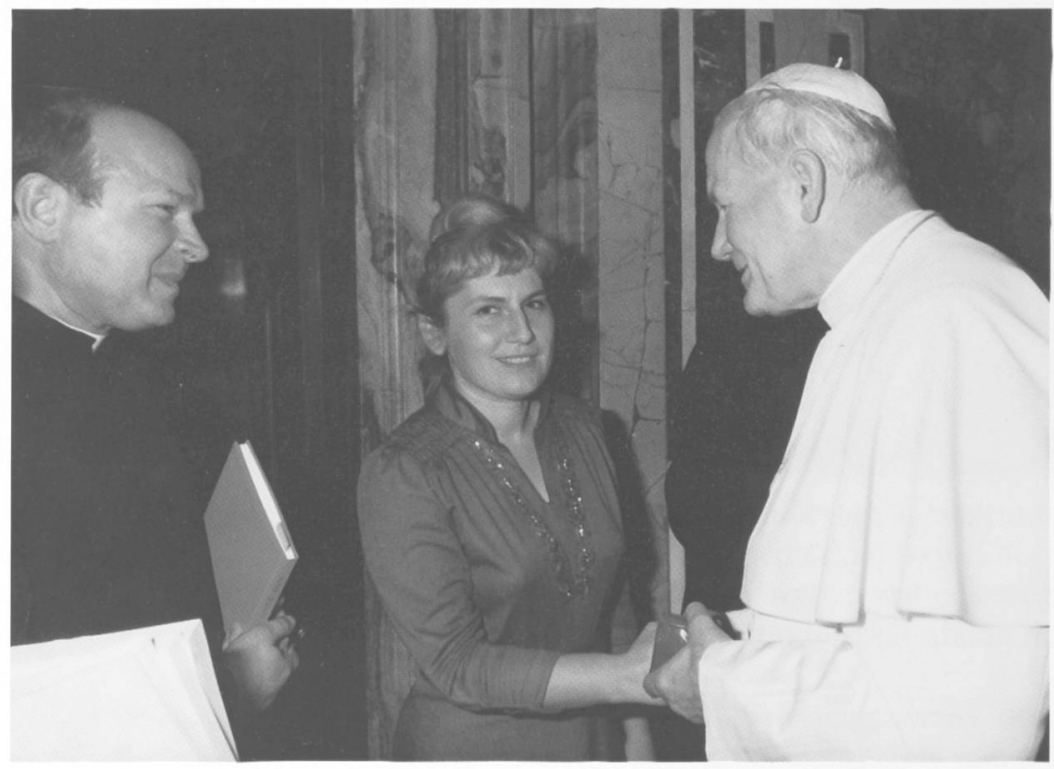

Fot. 3. Ks. F. Drączkowski i A. Stępniewska w rozmowie z Janem Pawłem II 


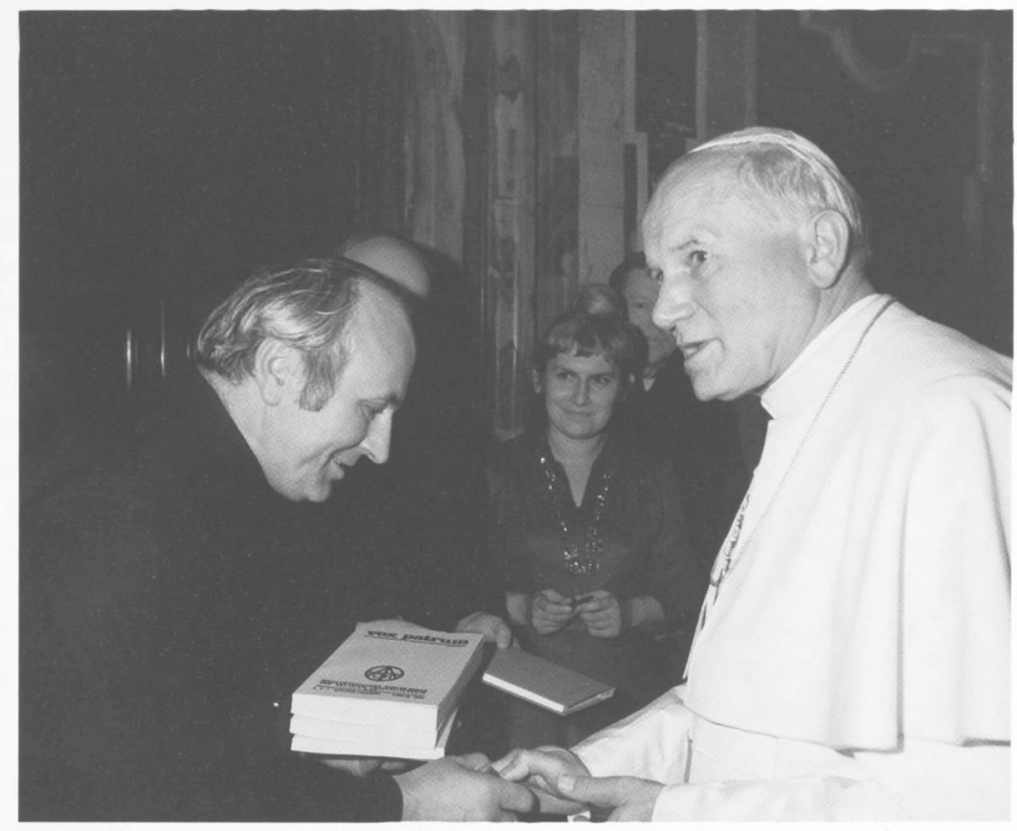

Fot. 4. Ojciec Święty gratuluje wydania „Vox Patrum”

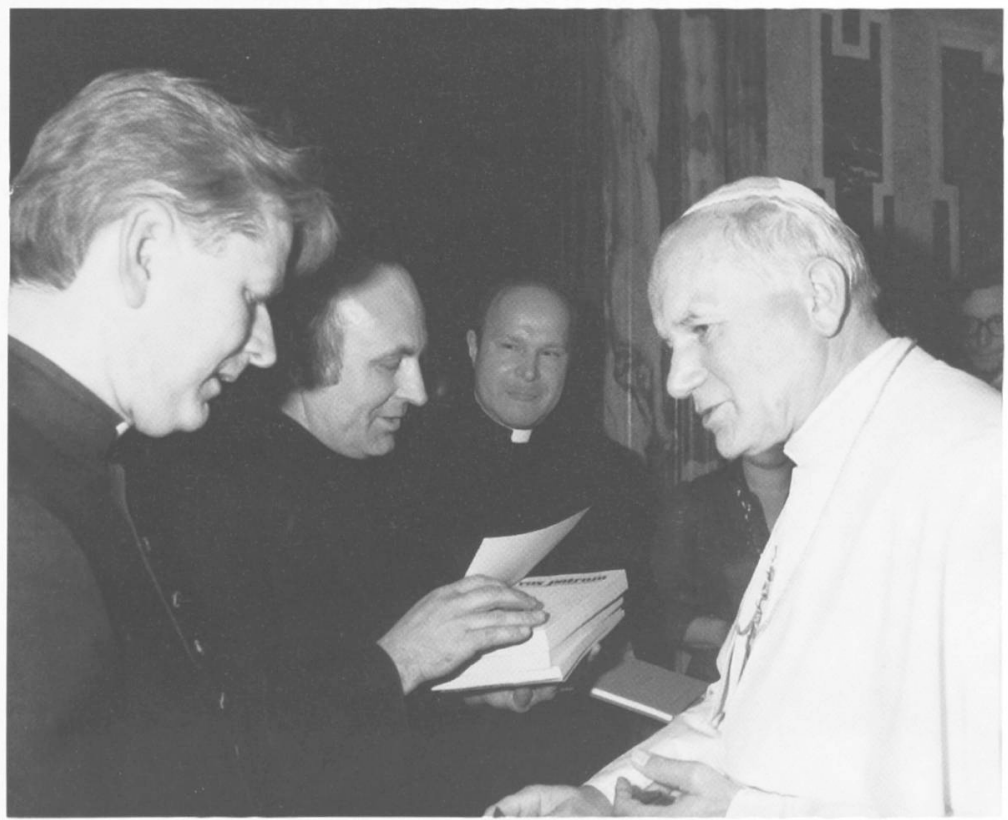

Fot. 5. Jan Paweł II w rozmowie z członkami Rady Naukowej „Vox Patrum” (od lewej: ks. A. Eckmann, ks. S. Longosz i ks. F. Drączkowski) 


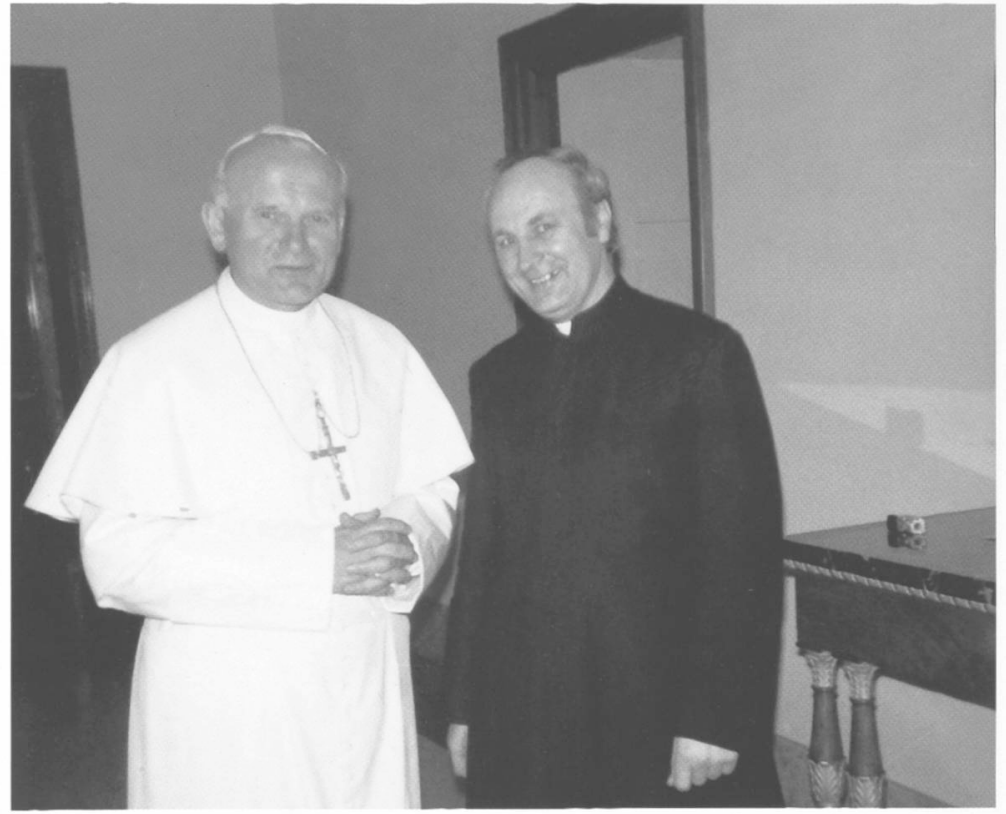

Fot. 6. Spotkanie Jana Pawła II z ks. S. Longoszem

w sprawie Instytutu Patrystycznego w Tarnowie

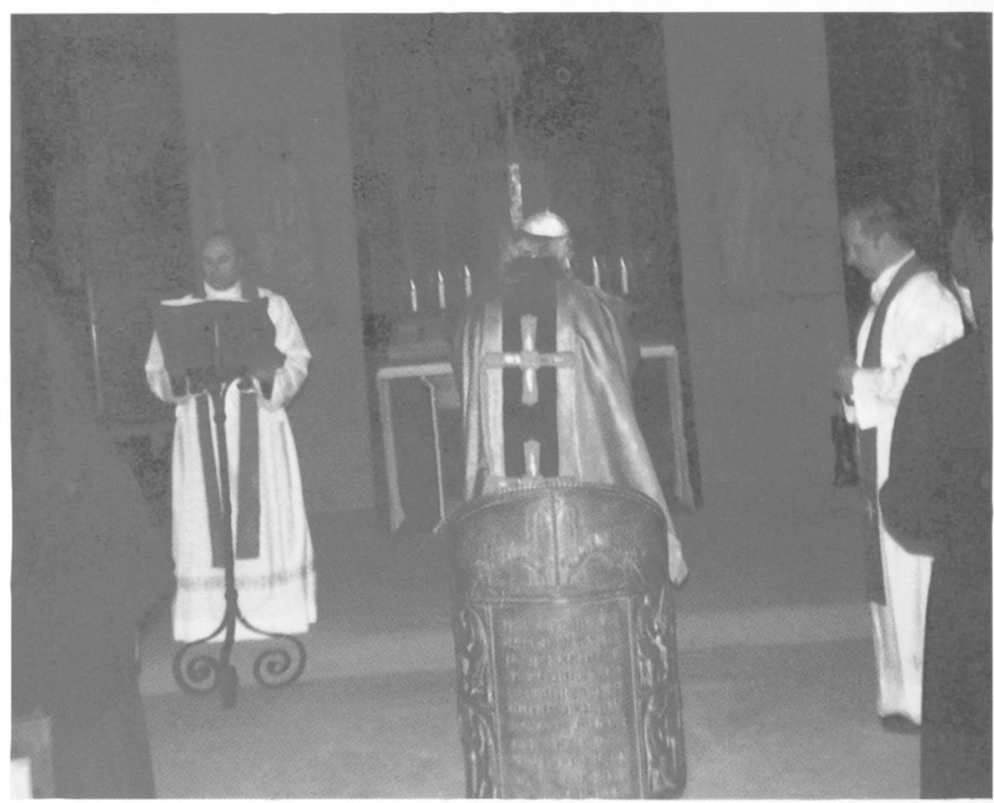

Fot. 7. Msza Święta koncelebrowana w Kaplicy Papieskiej w Rzymie. Z Ojcem Świętym odpawiają z lewej - ks. S. Longosz, z prawej-ks. S. Dziwisz 
patronatem św. Jana Chryzostoma. Miał się jednak cieszyć swoimi przewidywanymi w przepisach prawami i współpracować z miejscowym Instytutem Filozoficzno-Teologicznym (WSD). Jego celem miało być: l. zgłębianie nauki Ojców Kościoła, by z niego wynikało pełniejsze zrozumienie historii zbawienia i tajemnicy Chrystusa, pomocne w rozwiązywaniu problemów współczesnego życia chrześcijańskiego; 2. czerpanie z nauki Ojców Kościoła wzorców i korzyści duchowych dla współczesnego duszpasterstwa; 3. dostarczenie profesorom możliwości wyjaśniania i tłumaczenia pism Ojców Kościoła; 4. pogłębienie przez duchownych wiedzy patrystycznej, umożliwiające im osiąganie licencjatu, a nawet doktoratu z tej dziedziny.

Do jego władz miały należeć: Wielki Kanclerz Fakultetu Teologicznego, dyrektor Instytutu, dziekan Fakultetu Teologicznego, prezes Instytutu Patrystycznego, jego sekretarz oraz Rada Akademicka, w skład której mieli wchodzić wybrani profesorowie Instytutu i rektor Instytutu Filozoficzno-Teologicznego. Stopnie zaś akademickie, uzyskiwane w Instytucie, miały być podpisywane przez Wielkiego Kanclerza, dyrektora Instytutu, dziekana Fakultetu Teologicznego oraz prezesa i sekretarza Instytutu.

Jeśli chodzi o przedmioty nauczane w Instytucie, to miały nimi być przede wszystkim te dyscypliny, które mogą przynieść jak największą korzyść duszpasterstwu i życiu duchowemu wiernych. Dzieliły się zaś one najogólniej na trzy grupy: 1. filologiczne (język Ojców: grecki, łaciński i syryjski), 2. wprowadzające w kontekst historyczno-społeczny Ojców i ułatwiające zrozumienie ich nauki (metodologia i pomoce naukowe do studium Ojców, historia Kościoła starożytnego i filozofii starożytnej, archeologia i sztuka wczesnochrześcijańska, monastycyzm starożytny, początki prawa kościelnego, starożytne religie niechrześcijańskie, zarys historii starożytnej zwłaszcza okresu patrystycznego, herezje wczesnochrześcijańskie, ogólny zarys grecko-łacińskiej literatury klasycznej), 3. przede wszystkim teologia Ojców, wykładana tematycznie i analitycznie, ukazywana w rozwoju poszczególnych jej działów (egzegeza Pisma św., credo chrześcijańskie, nauka trynitarna, chrystologia, pneumatologia, eklezjologia, sakramentologia, liturgia, życie ascetyczne); należało do tego również czytanie i analiza wybranych pism Ojców (lectio Patrum). Dyscyplin tych miano nauczać kursorycznie i monograficznie przez co najmniej 4 lata po ukończonych studiach teologicznych (seminaryjnych): przynajmniej dwa lata do licencjatu i dwa do doktoratu (kurs doktorancki). Rok akademicki miał się rozpoczynać w pierwszym tygodniu października i dzielić się tradycyjnie na dwa semestry.

Słuchacze mieli się dzielić na zwyczajnych (kapłanów lub świeckich po maturze), którzy zmierzając do osiągnięcia stopni akademickich musieli zaliczyć wszystkie wykłady, uczęszczać na przepisane ćwiczenia i seminaria oraz zdać wymaganą ilość egzaminów, i na nadzwyczajnych (przynajmniej po maturze), którzy nie aspirując do stopni akademickich mogą uczęszczać na wybrane 
przez siebie zajęcia; wszyscy oni winni posiadać przynajmniej podstawową znajomość języka łacińskiego i elementarną języka greckiego. Do osiągnięcia stopni akademickich wymagane było zdanie (ustne lub pisemne) wszystkich przewidzianych egzaminów oraz zaliczenie odpowiednich ćwiczeń i seminariów; uznawane miały być wykłady, ćwiczenia i egzaminy zdane z tematyki patrystycznej w KUL, ATK lub Papieskich Fakultetach Teologicznych.

Profesorów według proponowanych statutów miał mianować dyrektor Instytutu Patrystycznego (czyli ks. bp ordynariusz miejscowy), a zatwierdzać Rada Wydziału Teologicznego w Krakowie. Dzielili się oni na zwyczajnych, którzy mieli przynajmniej doktoraty z teologii ze specjalizacją patrystyczną, i nadzwyczajnych, którzy nie posiadali takich kwalifikacji. Dzielili się oni ponadto na miejscowych (domestici) i zamiejscowych (externi), którymi byli zapraszani z innych Uczelni Wyższych specjaliści.

W otrzymanej od Kongregacji d/s Wychowania Katolickiego na przesłane doń dokumenty (zwłaszcza projekt statutów i programu studiów) odpowie$\mathrm{dzi}^{35}$, jej konsultor zasugerował szereg modyfikujących, ale niezbędnych do wprowadzenia zmian. Najpierw Instytut nie może być do Fakultetu ,agregowany”, ale ,inkorporowany”, bo stanowi tylko drugi jego cykl ze specjalizacją patrystyczną. Ordynariusz miejscowy nie może być dyrektorem Instytutu, mającym nad nim pełną władzę i mianującym m.in. uczących w nim profesorów, ale tylko Wicekanclerzem, do którego należą jedynie bezpośrednie (głównie finansowe) sprawy Instytutu, a pełną władzę nad nim będą sprawować Wielki Kanclerz, Rada Wydziału i jej dziekan, proces zaś wyłaniania prezesa i profesorów Instytutu winien się rozpoczynać od Rady Akademickiej Instytutu poprzez Wicekanclerza, Radę Wydziału i Wielkiego Kanclerza, który dokonuje aktu nominacji; podobnie stopni naukowych udziela Wydział poprzez Instytut. Konsultor sugeruje ponadto, by statuty z jednej strony dostosować szczegółowiej do rzymskich Normae ad Universitatis vel Facultatis statuta conficienda i do statutów Wydziału Teologicznego w Krakowie, z drugiej zaś, zwłaszcza odnośnie do profesorów, lepiej je adaptować do postulatów uniwersyteckiego prawa polskiego, gdzie wymaga się habilitacji, oraz zapisać jasno ich kategorię i proces ich wyłaniania; należy też w nich uwzględnić miejsce sekretariatu Instytutu i określić jasno prawa urzędującego w nim sekretarza Instytutu. Domaga się również zwiększenia liczby profesorów ze specjalizacją patrystyczną, a w innym piśmie - jasnego zagwarantowania odpowiednich funduszów na specjalistyczną bibliotekę i opłatę profesorów Instytutu. W przyszłości zaś oficjalna prośba o erygowanie Instytutu Patrystycznego w Tarnowie, skierowana do Kongregacji przez Wielkiego Kanclerza, winna być poparta, zarówno pisemną pozytywną opinią Fakultetu Teologicznego o programie i statutach tworzonego Instytutu, jak i rekomendacją Komisji Episkopatu d/s Nauki

35 Por. S. Longosz, Instytut Patrystyczny w Tarnowie, VoxP 19 (1999) t. 36-37, 135-158. 
i Studiów Wyższych stwierdzającą, że on odpowiada wymogom polskiego prawa kościelnego i uniwersyteckiego ${ }^{36}$.

Po otrzymaniu powyższej odpowiedzi ks. biskup J. Ablewicz w niedługim czasie zrezygnował z dalszych starań o erygowanie Instytutu Patrystycznego w Tarnowie. Nie wiemy, jakie były tego bezpośrednie powody. Być może brak dostatecznej miejscowej patrystycznej kadry profesorskiej lub względy finansowe, a może świadomość, że w tej stworzonej przez siebie instytucji sam niewiele miałby do powiedzenia poza obowiązkiem jej utrzymywania.

Niedługo potem zlikwidowano utworzony w gmachu Wyższego Seminarium Duchownego Zakład Patrystyczny (lectorium), a zgromadzony w nim specjalistyczny księgozbiór przeniesiono do biblioteki seminaryjnej. Wkrótce zapomniano też o organizowanym w Tarnowie Instytucie Patrystycznym, a była to niewątpliwie ciekawa i godna pamięci inicjatywa w historii polskich studiów nad antykiem chrześcijańskim, w której budowanie angażował się przyszły papież.

\title{
JOANNES PAULUS II - PROMOTOR STUDIORUM DE ANTIQUITATE CHRISTIANA IN POLONIA
}

\author{
(Argumentum)
}

Hac in dissertatiuncula, plenissima variorum allatorum documentorum, in memoriam revocantur merita primum cardinalis Caroli Wojtyła, postea Joannis Pauli II papae in promovenda studia Polonorum de antiquitate christiana tribus in campis: in constituendo Instituto Studiorum de Antiquitate Christiana in Catholica Universitate Lublinensi (1969), in erigenda Societate Patristica Polonorum (1977) necnon in creando Instituto Patristico Tarnoviae nondum tamen terminato.

${ }^{36}$ Por. Dokument Kongregacji „Circa il costituendo Istituto Patristico Tarnoviense”, tamże s. 153-156. 